\title{
A Structured Approach to Recover Valuable Compounds from Agri-food Side Streams
}

\author{
Mónica Moreno-González ${ }^{1} \cdot$ Marcel Ottens ${ }^{1}$ \\ Received: 20 September 2020 / Accepted: 14 April 2021 / Published online: 14 May 2021 \\ (C) The Author(s) 2021
}

\begin{abstract}
Food side streams contain useful compounds such as proteins, sugars, polyphenols, and amino acids that might get discarded during processing. The concentration of these components may be low (e.g., fruit side streams are mainly composed by water, around $90 \%$, while polyphenol content in rapeseed meal is less than $3 \%$ dry weight) and therefore effective separation techniques should be evaluated. The aim of this review is to identify the different process steps (like pretreatment, volume reduction, phase change, solid removal, purification, and formulation) required to recover high-value products from agri-food residues. It reviews different plant-based byproducts as sources (cereal bran, fruit pomace, oilseed meals, fruit wastewater) of valuable compounds and discusses the relevant technologies required for processing (such as extraction, adsorption, crystallization, drying, among others). A structured approach to design recovery processes presented focused on high purity products. This work demonstrates that multiple high-value products can be recovered from a single agri-food side stream depending on the processing steps and the origin source (strong and soft structures and wastewater).
\end{abstract}

Keywords Valorization $\cdot$ Food side streams $\cdot$ Protein $\cdot$ Polyphenols $\cdot$ Separation technologies

\section{Introduction}

The increasing waste generation and the limited availability of natural resources have motivated the scientific community to investigate possibilities to recover valuable products from different waste streams such as wastewater and agri-food residues.

Food industry is recognized as one of the most important industries in the world but generates a significant amount of waste (Virtanen et al., 2016). On December 2015, the European Commission established a package to motivate EU members to move in the direction of a more circular economy (European Commission, 2017) and has taken the issue of food waste generation with seriousness. According to European Commission (2014), most of the waste is produced by the food manufacturing sector, and by 2020 is expected to rise to 126 million tons compared to 96 million tons generated in 2007 (European Commission, 2011). In order to contribute

Marcel Ottens

M.Ottens@tudelft.nl

1 Department of Biotechnology, Delft University of Technology, van der Maasweg 9, 2629HZ Delft, the Netherlands to this initiative, side streams of food industry can become inputs of other processes as they are sources of proteins, lipids, complex carbohydrates, and nutraceuticals. Therefore, valorization and recovery of high-value products from food byproducts is an attractive area that has been investigated lately around the globe (Virtanen et al., 2016). Recently, it has been proven that the conversion of biomass waste to bulk chemicals might be more profitable than its conversion to animal feed or transportation fuel (Tuck et al., 2012). In addition, increasing protein demand due to population growth could be satisfied by using plant-based residues such as proteins from canola meal resulted to be competitive and suitable for human consumption (Wanasundara et al., 2016).

Among the generated food byproducts, plant-based byproducts include fruit pomace, oilseed meals, cereal brans, wastewaters, etc. These residues are rich sources or dietary fiber (cellulose, hemicellulose, and lignin) and could be used within the biorefinery concept to produce biofuels or biochemicals from their respective hydrolysates. However, proteins and other nutraceuticals, mainly phenolic compounds (presented in the outer layers of most plant-based products (Naczk \& Shahidi, 2006)) could be recovered. Extraction of proteins and nutraceuticals might be a fundamental step in 
order to recover more valuable compounds from food byproducts.

This review describes and discusses the different valuable products presented exclusively in plant-based byproducts, such as oilseed meals, pea pods, cereal brans, and fruit pomace, among others. This is followed by the discussion of the different process techniques needed to recover these valuable compounds. Commonly, in these agri-food side streams, valuable compounds concentration is low (diluted systems, e.g., wastewater), and additionally, the presence of other low values impurities such as off-flavors and insoluble solids represents a technological challenge. Recovery and purification of the valuable compounds presented will additionally depend on the composition and volume of the side streams. Therefore, it is important to define different process stages. Combining the information available in literature for processing (Bongers \& Almeida-Rivera, 2009; Galanakis, 2015) with some modifications, a generalized process flow scheme as the one defined in Fig. 1, could be applied as a starting point for the process synthesis of agri-food side streams.

The objective of the pretreatment step is to break the strong-linked structure of (solid) agri-food residues, such as cereal bran, in order to facilitate following processing steps; this might lead to recovery and purification of dietary fibers, or to conversions on sugars into biofuels. It is important to keep in mind that not all agri-food residues possess this strong matrix; therefore, this step is dependent of the source and the products to be recovered. For voluminous fruit and vegetable wastewaters, a volume reduction step is suggested at the beginning of the purification train, with the objective to concentrate and decrease volumetric load in the following steps. The third step, phase change, aims to extract the valuable components to a (different) liquid phase. The remained solids are removed (solid removal) and could be additionally treated for recovery of other products such as dietary fiber. The obtained liquid stream undergoes to a purification step, where the different compounds are separated or converted into other (bio) chemicals (e.g., sugars into bioethanol) and finally the last stage corresponds to formulation. This last stage has a main objective to get the product to its final form, e.g., powders and emulsions. The different unit tasks that can be applied in each stage of the processing of agri-food products are additionally indicated in Fig. 1.

This work discusses the different technologies for processing agri-food side streams to recovery valuable compounds as described in Fig. 1. Moreover, it provides an overview of possible purification processes of proteins, polyphenols, and dietary fibers from different plant-based starting materials.

\section{Food Side Streams: Valuable Products}

The co-streams from food can originate from several branches mainly divided in two main groups, plant- and animal-based. This study will only focus on plant-based byproducts and their valuable compounds. Plant-based byproducts can be additionally subdivided in four groups namely: (1) cereals, (2) roots and tubers, (3) oil crop and pulses, and (4) fruits and vegetables (Galanakis, 2012). The average composition and the distribution of the different nutrients from plant-based sources are presented in Fig. 2, while Table 1 summarizes different plant-based side stream sources and the valuable products that could be recovered.

Cereal grains possess three botanical parts, endosperm, germ and bran. The bran is usually separated from the cereal grain, during milling operations, as it might have negative effects with the final product (Rosa-Sibakov et al., 2015) such as darker colors. However, cereal brans are sources of

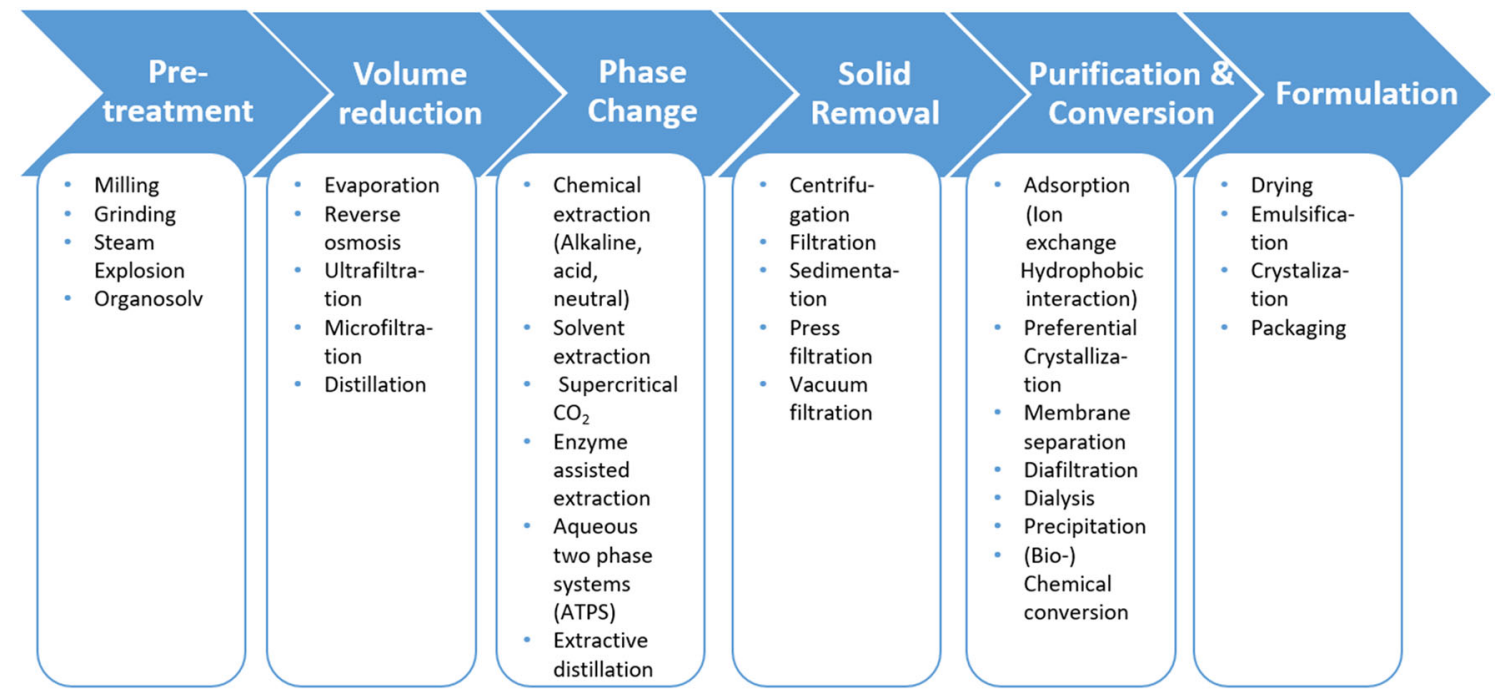

Fig. 1 Process flow scheme for processing of agri-food side streams 
Table 1 Sources of plant-based byproducts and the potential valuable compounds

\begin{tabular}{|c|c|c|c|}
\hline Source & Side streams & Valuable compounds & Reference \\
\hline \multicolumn{4}{|l|}{ Cereals } \\
\hline Barley & $\begin{array}{l}\text { Bran } \\
\text { Malt } \\
\text { Straw }\end{array}$ & $\begin{array}{l}\text { Polyphenols (hydroxycinnamic acids) } \\
\text { Protein } \\
\text { Dietary fiber }\end{array}$ & Ahmad et al. (2019); Szwajgier and Borowiec (2012) \\
\hline Corn & $\begin{array}{l}\text { Cods } \\
\text { Husk } \\
\text { Silks }\end{array}$ & $\begin{array}{l}\text { Dietary fiber (cellulose and xylans) } \\
\text { Minerals (P, K, Mg) } \\
\text { Proteins } \\
\text { Polyphenols } \\
\text { Starch }\end{array}$ & Lau et al. (2019); Pfaltzgraff et al. (2013) \\
\hline Oat & $\begin{array}{l}\text { Bran } \\
\text { Straw }\end{array}$ & $\begin{array}{l}\beta \text {-glucan } \\
\text { Polyphenols }\end{array}$ & Patsioura et al. (2011) \\
\hline Rice & $\begin{array}{l}\text { Bran } \\
\text { Straw }\end{array}$ & $\begin{array}{l}\text { Proteins } \\
\text { Dietary fiber } \\
\text { Polyphenols } \\
\text { Lipids } \\
\text { Xylans }\end{array}$ & $\begin{array}{l}\text { Prakash and Ramaswamy (1996); Sohail et al. (2017); } \\
\text { Liu et al. (2019); Ahmad et al. (2019); Orthoefer } \\
\text { (2005) }\end{array}$ \\
\hline Wheat & $\begin{array}{l}\text { Bran } \\
\text { Straw }\end{array}$ & $\begin{array}{l}\text { Proteins } \\
\text { Arabinoxylan } \\
\beta \text {-glucan } \\
\text { Polyphenols (ferulic, sinapic and } \\
\text { p-coumaric, flavonoids) } \\
\text { Cellulose } \\
\text { Xylans }\end{array}$ & Balandrán-Quintana et al. (2015); Ahmad et al. (2019) \\
\hline \multicolumn{4}{|l|}{ Root and tubers } \\
\hline Asparagus & Roots & $\begin{array}{l}\text { Carbohydrates } \\
\text { Phenolics (flavonoids and } \\
\text { hydroxycinnamic acids) } \\
\text { Protein } \\
\text { Saponins } \\
\text { Oil }\end{array}$ & Zhang et al. (2019) \\
\hline Carrots & $\begin{array}{l}\text { Pomace } \\
\text { Peel }\end{array}$ & $\begin{array}{l}\text { Dietary fiber } \\
\alpha \text { - and } \beta \text {-carotene } \\
\text { Sugars } \\
\text { Uronic acids } \\
\text { Carotenoids }\end{array}$ & $\begin{array}{l}\text { Sharma et al. (2012); Nawirska and Kwaśniewska } \\
\text { (2005) }\end{array}$ \\
\hline Cassava & $\begin{array}{l}\text { Peels } \\
\text { Pomace } \\
\text { Bagasse }\end{array}$ & $\begin{array}{l}\text { Starch } \\
\text { Dietary fiber } \\
\text { Protein } \\
\text { Lipids } \\
\text { Starch }\end{array}$ & $\begin{array}{l}\text { Versino et al. (2015); Ubalua (2007); Mullen et al. } \\
\text { (2015) }\end{array}$ \\
\hline Potato & $\begin{array}{l}\text { Peel } \\
\text { Stillage (distillery water) } \\
\text { Pulp }\end{array}$ & $\begin{array}{l}\text { Dietary fiber } \\
\text { Proteins } \\
\text { Polyphenols (chlorogenic and } \\
\quad \text { hydroxycinnamic acid) } \\
\text { Sugars } \\
\text { Vitamins (B) } \\
\text { Amino acids } \\
\text { Pectin }\end{array}$ & $\begin{array}{l}\text { Camire et al. (1997); Arapoglou et al. (2010); } \\
\text { Rodriguez de Soltillo et al. (1994); Mullen et al. } \\
\text { (2015) }\end{array}$ \\
\hline \multicolumn{4}{|l|}{ Oil crops and pulses } \\
\hline Hazelnut/almond/peanut & $\begin{array}{l}\text { Hard shells } \\
\text { Skin } \\
\text { Leaf } \\
\text { Hull }\end{array}$ & $\begin{array}{l}\text { Phenolic compounds (catechin, } \\
\text { hydroxycinnamic acids, phenyl } \\
\text { benzoic acid) }\end{array}$ & Siriwardhana and Shahidi (2002); Shahidi et al. (2007) \\
\hline Oilseed & $\begin{array}{l}\text { Oilseed meals (rapeseed, } \\
\text { sunflowers, flaxseed, } \\
\text { cotton) }\end{array}$ & $\begin{array}{l}\text { Proteins } \\
\text { Polyphenols } \\
\text { Dietary fiber }\end{array}$ & Lomascolo et al. (2012); Wanasundara (2011) \\
\hline Pea & $\begin{array}{l}\text { Pod } \\
\text { Husk } \\
\text { Broken grains } \\
\text { Powder } \\
\text { Cotyledon }\end{array}$ & $\begin{array}{l}\text { Dietary fiber } \\
\text { Proteins } \\
\text { Phenolics (hydroxycinnamic acids) }\end{array}$ & $\begin{array}{l}\text { Mateos-Aparicio et al. (2010); Mateos-Aparicio et al. } \\
\text { (2012) }\end{array}$ \\
\hline
\end{tabular}


Table 1 (continued)

\begin{tabular}{|c|c|c|c|}
\hline Source & Side streams & Valuable compounds & Reference \\
\hline \multicolumn{4}{|c|}{ Fruits and vegetables } \\
\hline Apple & $\begin{array}{l}\text { Peel } \\
\text { Pomace } \\
\text { Seeds }\end{array}$ & $\begin{array}{l}\text { Dietary fiber } \\
\text { Pectin } \\
\text { Polyphenols (catechins and } \\
\quad \text { proanthocyanidins) }\end{array}$ & Sudha (2011); Mourtzinos and Goula (2019) \\
\hline Pineapple & $\begin{array}{l}\text { Peel } \\
\text { Core } \\
\text { Stem } \\
\text { Shells }\end{array}$ & $\begin{array}{l}\text { Dietary fiber } \\
\text { Proteins (bromelain) } \\
\text { Starch } \\
\text { Polyphenols (myricetin, salicylic acid, } \\
\quad \text { and tannic acid) }\end{array}$ & $\begin{array}{l}\text { Roda and Lambri (2019); Larrauri et al. (1997); Seguí } \\
\text { Gil and Fito Maupoey (2018) }\end{array}$ \\
\hline Orange & $\begin{array}{l}\text { Peel } \\
\text { Pomace }\end{array}$ & $\begin{array}{l}\text { Dietary fiber } \\
\text { Essential oils (limonene) } \\
\text { Pectin } \\
\text { Phenolics (flavonoids) } \\
\text { Carotenoids }\end{array}$ & $\begin{array}{l}\text { Espina et al. (2011); May (1990); } \\
\text { Chedea et al. (2010); Aravantinos-Zafiris et al. } \\
\text { (1992); Scordino et al. (2007) }\end{array}$ \\
\hline Tomato & $\begin{array}{l}\text { Pomace } \\
\text { Peels } \\
\text { Seeds }\end{array}$ & $\begin{array}{l}\text { Lycopene } \\
\text { Dietary fiber } \\
\text { Pectin } \\
\text { Polysaccharides } \\
\text { Proteins } \\
\text { Oil }\end{array}$ & Lu et al. (2019) \\
\hline Broccoli & $\begin{array}{l}\text { Pomace } \\
\text { Stems } \\
\text { Leaves }\end{array}$ & $\begin{array}{l}\text { Proteins } \\
\text { Dietary fiber } \\
\text { Polyphenols (chlorogenic, } \\
\quad \text { neochlorogenic, and quinic acids) }\end{array}$ & Shi et al. (2019) \\
\hline
\end{tabular}

a

\section{Cereals}

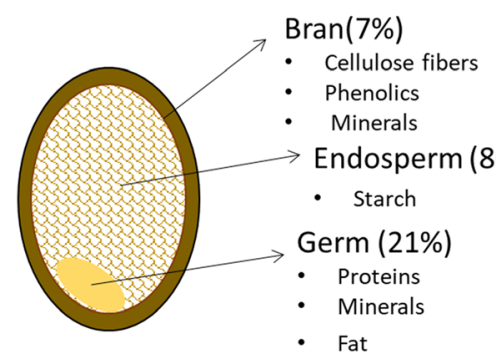

Oilseeds

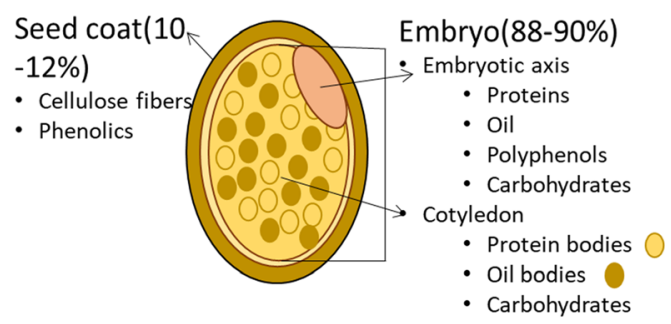

Pulses

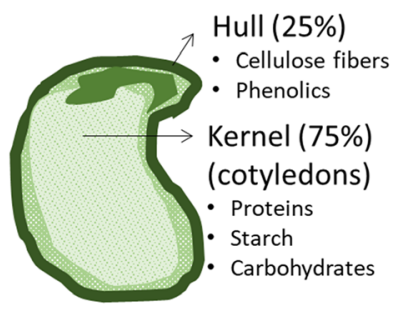

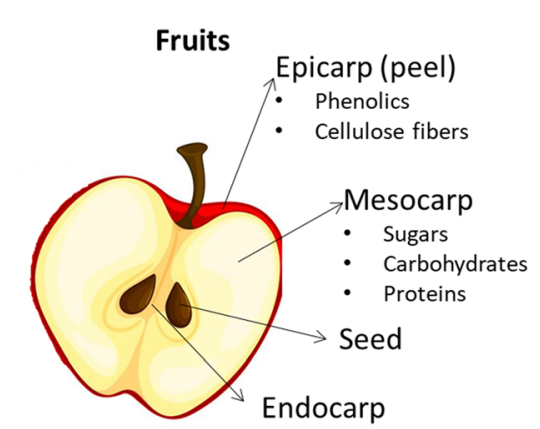

Endocarp

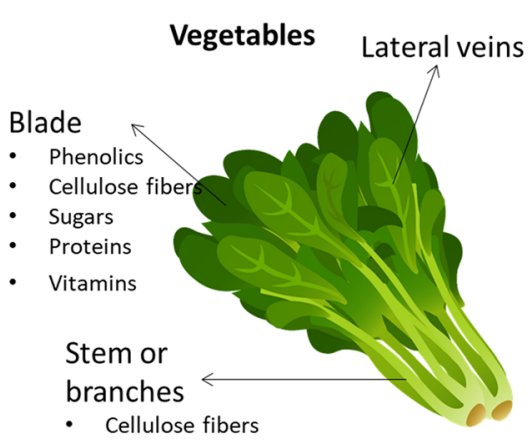

- Cellulose fibers
Fig. 2 Plant-based sources composition. a Nutrient distribution, b proximate composition (dry weight). Adapted from Naczk and Shahidi (2006), Butnariu and Butu (2015), Carrillo-López and Yahia (2019),
González-Pérez and Arellano (2009), Islam and Ma (2016), List (2016), Rosell and Garzon (2015), Shukla et al. (1992) 
b
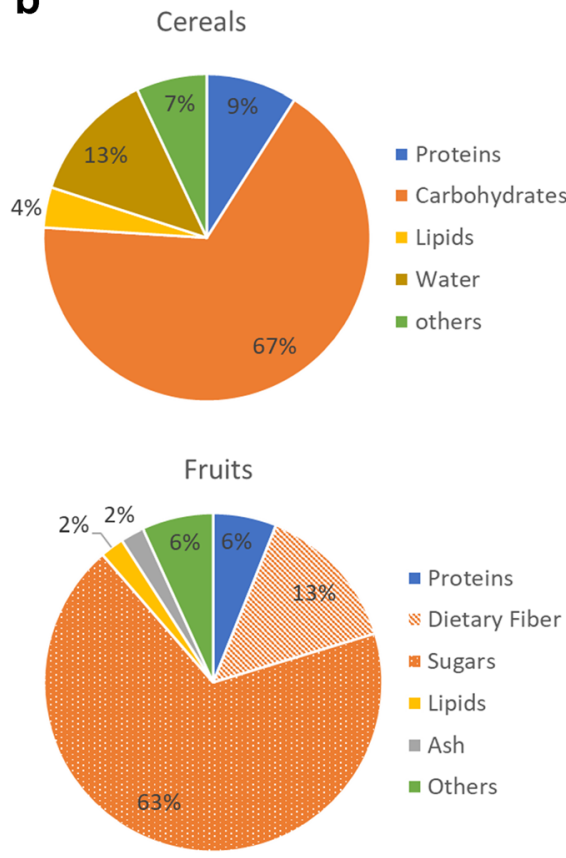
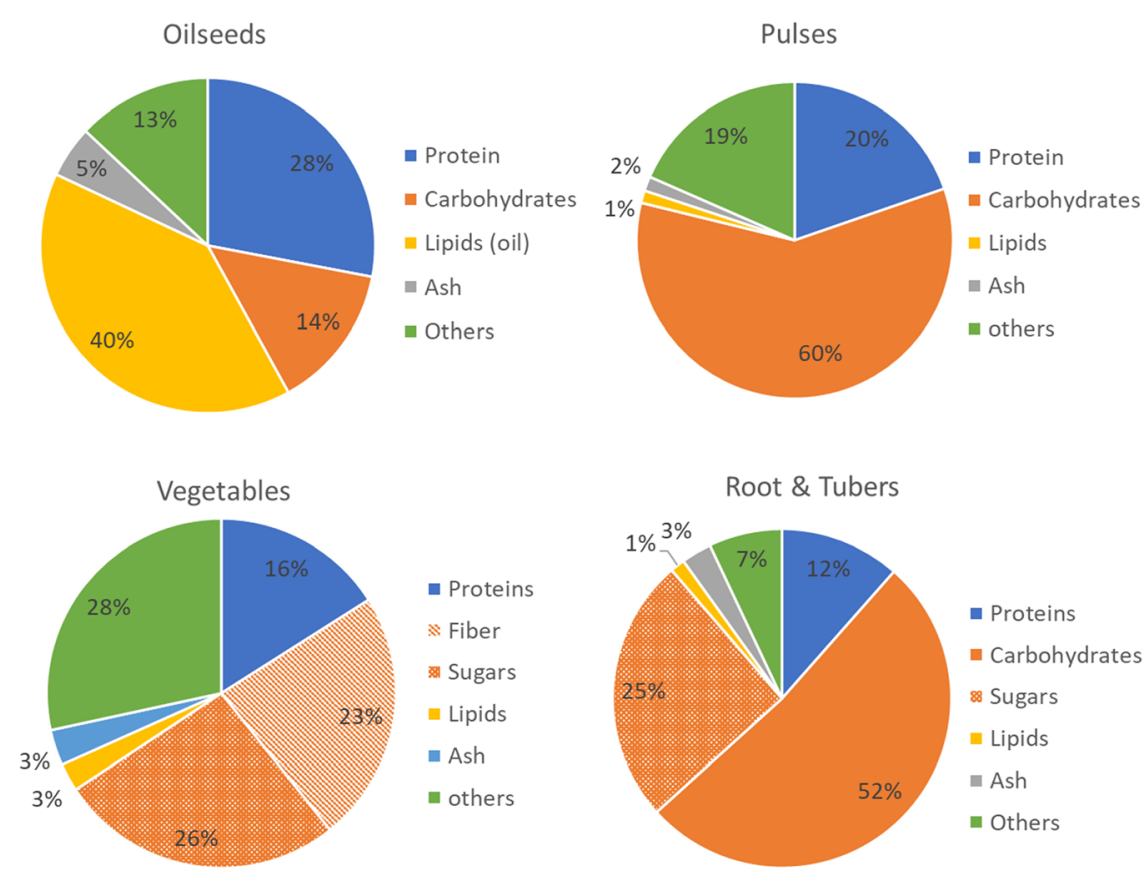

Fig. 2 (continued).

nutritional compounds such as polyphenols, dietary fibers, and minerals (Heiniö et al., 2016). Different studies have shown the potential of using wheat bran as a source of valuable compounds. Rosa-Sibakov et al. (2015) compared the application of wheat bran in different baking products to increase their nutritional value. The study of Ahmad et al. (2019) demonstrated the different polyphenols available in wheat, barley, millet, and sorghum brans, assessing the antioxidant profiles, showing that millet and sorghum brans contain higher antioxidant activities than wheat and barley. Other byproducts obtained from the cereal sources are husks and straw which are rich on dietary fibers, glucoarabinoxylans (Hollmann \& Lindhauer, 2005), and proteins (Prakash \& Ramaswamy, 1996). Wheat, oat, barley, and rice straw are rich lignocellulosic biomasses (Pfaltzgraff et al., 2013) and can be used in biorefineries to obtain second-generation bioethanol or building blocks for other chemicals.

Fruit and vegetable side streams involve peels, leaves, pomace, and kernels, which are generated depending of the processing technology (juices, jams canning, jellies, etc.). The side streams generated are mostly composed of water and hydrocarbons (80-90\%) with a low percentage of fat and proteins (Mirabella et al., 2014; Mullen et al., 2015). Orange peel is a rich source of essential oils (limonene), carotenoids, phenolic antioxidants, and pectin (Aravantinos-Zafiris et al., 1992; Chedea et al., 2010; Espina et al., 2011; May, 1990). A broad range of food products can be derived from this fruit namely sweet orange oil, orange blossom, honey, or marmalade (Siles López et al., 2010). Residues from pigmented orange pulp were valorized by Scordino et al. (2007) and successfully treated to recover sugars, citric acid, and pectin. Moreover, citrus fruits are rich on flavonoids, D-limonene, pulp, molasses (sugars), and essences (Virtanen et al., 2016). Around 25\% of the processed apple is represented by apple pomace (Rodríguez Madrera et al., 2013) and it is a natural source for commercial pectin around the world. In addition, it is also characterized by a high content of carbohydrates (cellulose, hemicellulose) and important polyphenols such as catechins, flavanols, hydroxycinnamates, and anthocyanins (Mourtzinos \& Goula, 2019). Grape pomace, the byproduct of wine production, are rich sources of dietary fiber, oil, and phenolic compounds (anthocyanins and flavanols) (Bordiga et al., 2019), while tomato pomace is rich source of lycopene (principal carotenoid) proteins, dietary fiber, and oil (Lu et al., 2019). In addition, olive byproducts, olive mill wastewater, pomace, leaves, and seed are important sources of phenolic compounds, pectin, polysaccharides, and lignocellulosic fibers (Nunes et al., 2016).

According to the Food and Agriculture Organization of the United Nations (FAO) (2020), cassava, potatoes, sweet potatoes, yams, and carrots are the main root and tubers produced worldwide. Many bioactive compounds can be found in the byproducts of these food products, such as dietary fiber, proteins, antioxidants, and starch (Arapoglou et al., 2010; Camire et al., 1997; Mullen et al., 2015; Nawirska \& Kwaśniewska, 2005; Rodriguez de Soltillo et al., 1994; Sharma et al., 2012; Ubalua, 2007; Versino et al., 2015). For instance, potato peel composition consists mainly of dietary fiber (around 50\%) 
(Camire et al., 1997) and phenolic compounds (Schieber \& Saldaña, 2009). Polyphenol antioxidative activity, from potato peel extracts, has been evaluated by Rodriguez de Soltillo et al. (1994) showing a similar performance of butylated hydroxyanisole (BHA) which is a food additive commonly used in food products to prevent rancidity (Prival, 2003). Carrot pomace accounts around $50 \%$ of the raw material during carrot juice production. This pomace still contains a significant amount of $\alpha$ - and $\beta$-carotene, which can be recovered and used as functional ingredient (Stoll et al., 2003). Similarly, sweet potato peels contain important antioxidants with chlorogenic acid, the highest phenolic in the root tissues (Truong et al., 2007).

At last, oilseed (flaxseed, canola/rapeseed, sunflower, and cotton) meals are rich sources of proteins, mainly storage proteins of two types, globulins and albumins (Lomascolo et al., 2012; Wanasundara, 2011). Fleddermann et al. (2013) evaluated the amino acids composition of canola meal proteins and compared with the one from soy protein for human nutrition. The authors demonstrated that the bioavailability of the proteins from canola protein isolate and soy protein isolate is similar, proving that canola proteins are relevant for nutrition (Fleddermann et al., 2013). In addition, oilseed meals are sources of polyphenols, such as sinapic acid (mayor phenolic acid in rapeseed) (Vuorela et al., 2004) which possesses antioxidant, antimicrobial, and anti-inflammatory properties (Nićiforović \& Abramovič, 2014).

Beans, chick peas, lentils lupins, and peas are the most cultivated and consume pulses (Food and Agriculture Organization of the United Nations (FAO), 2020). The byproducts generated after processing pulses include broken grains, husks, powder, unprocessed seeds, and shriveled pulses (Mullen et al., 2015). Mateos-Aparicio et al. (2010) evaluated byproducts of pea, broad bean, and okara (soybean byproduct) as rich sources of dietary fiber and polyphenols (Mateos-Aparicio et al., 2012). Moreover, the authors identified high quantity of vegetable proteins (around 30\% dry matter) and fat (8.5\% composed by linoleic and oleic acid) in okara which could be potentially recovered.

Using the process scheme presented in Fig. 1 and applying well-established methodologies such as the 5-stage universal recovery strategy proposed by Galanakis (2012) or the product-driven process synthesis (Almeida-Rivera et al., 2016), the processing of these agri-food side streams could be defined.

\section{Plant-Based Byproducts Processing: Recovery and Purification Techniques}

After the identification of the valuable components, processing of food side streams will undergo several steps (Fig. 1) and actual process synthesis will require different unit tasks.
Depending on the source origin, some of the steps presented in Fig. 1 could be removed. In this work, source origin is divided in three groups: (1) lignocellulosic biomass which is characterized by plant fibers with a strong structure (e.g., cereal brans, oilseed meals), (2) fruit and vegetable pomaces (soft structures), and (3) fruits and vegetable wastewater (e.g., olive mill wastewater) (Fig. 3).

Considering strong structure side streams, such as bran from cereals, it has been proved that mechanical and thermal treatments (Agbor et al., 2011) of these solids improve the subsequent steps of the processing (pretreatment). The next step would correspond to the extraction of the components from the plant-based matrix to a liquid state (phase change). Depending on the conditions and medium to be used during the extraction, other components (valuable and non-valuable) might be co-extracted; therefore, separation and purification of the target components is required (solid removal and purification). Lastly, the final product will be formulated with a drying phase to remove water and generate the product form (e.g., powder).

For soft matrixes, such as fruit pomaces, pretreatment might not be needed and extraction of valuable products could be directly applied followed by purification and formulation, while for food wastewater streams, a volume reduction step is important in order to concentrate the streams and reduce the large volume generated. This will additionally benefit the overall process as smaller equipment would be needed for processing.

The following paragraphs of this section describe and discuss the different technologies that have been applied for processing plant-based residues (milling and pretreatment, extraction, purification, and formulation). It gives especially attention to adsorption as it proves to be the most promising purification technique for recovery of valuable products. Note that the downstream processing of the plant-based side streams will be dictated by the components to be recovered and the nature of the source.

\section{Milling and Pretreatment of Agri-food Byproducts}

Milling is a common operation in cereal, legumes, and oilseed processing as this operation is generating several byproducts such as hulls, husk, seed coat, and bran, among others. As previously mentioned, these byproducts are rich in bioactive compounds such as polyphenols, proteins, or dietary fibers (cellulose, hemicellulose). If the aim is to recover proteins and polyphenols, these byproducts can be sent to the extraction phase after grinding, used to homogenize particle size.

A byproduct from cereals is lignocellulosic biomass that can be implemented in a biorefinery concept for the production of sugars and further conversion into biofuels or other chemicals. When this is intended, a pretreatment step is required in order to make the enzymes or enzyme-producing 
Fig. 3 Process flow scheme depending on source origin. Different process steps are indicated in each concentric circle. Three sources: strong plant matrix (center circle position: lower), soft plant-based matrix (center circle position: upper right), and wastewater (center circle position: upper left). Processing steps start from the center of the figure to outside. Uncolored part of concentric circles indicates the process step that is not required for that source type

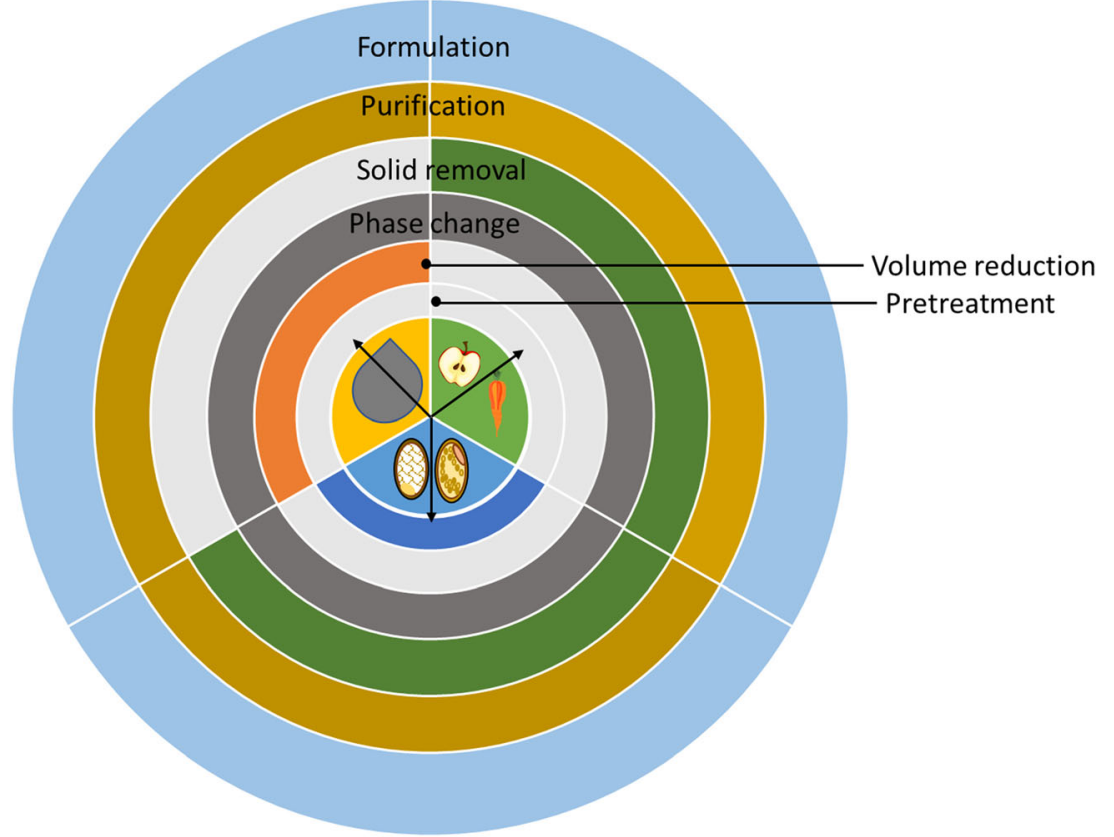

microorganisms accessible to the plant matrix. Many lignocellulosic biomass pretreatment techniques have been developed since early 2000 which involve mechanical pretreatments, such as physical pretreatment (milling), physicochemical pretreatments, and chemical and biochemical pretreatments. For further information about lignocellulosic pretreatment, the reader is referred to the work of Agbor et al. (2011), Sun et al. (2016), and K. Zhang et al. (2016).

The goal of pretreatment is to increase the accessibility of enzymes, to hydrolyze cellulose and hemicellulose into reducing sugars, available in the solid biomass. Chemical and biochemical pretreatments are often the extraction methods for other compounds such as proteins and polyphenols which are discussed in the following section.

\section{Valuable Compounds Extraction from Agri-food Byproducts}

Proteins, polyphenols, and soluble dietary fiber (oligosaccharides) can be co-extracted from different plantbased side streams. Extraction techniques can be classified into chemical, physical-chemical, and biochemical extraction (Contreras et al., 2019).

Among chemical extraction, solvent extraction and aqueous extraction have been widely applied. Capellini et al. (2017) developed a new method to extract oil from rice bran using safe solvents (ethanol and isopropanol) and mixtures of these solvents with water. The authors obtained around $80 \%$ yield of oil with pure ethanol and isopropanol. Additionally, the authors identified that the yield of co-extracted proteins varied up to $20 \%$ depending on the solvent, water content, and extraction temperature. The remained protein fraction stays in the defatted rice bran meal; however, the type of solvent and extraction conditions might affect the solubility and functional properties of the proteins.

Traditionally, pectin is extracted mainly from orange peel and apple pomace, in which pectin content ranges from 20 to $40 \mathrm{~g} / 100 \mathrm{~g}$ on dry weight basis (Kulkarni \& Vijayanand, 2010), through a process called conventional acid extraction. It makes use of hot water acidified with a mineral or organic acid (e.g., $\mathrm{H}_{2} \mathrm{SO}_{4}$ ); however, the use of strong acid leads to the generation of toxic waste, which should be neutralized before disposal. Additionally, the high temperature and long extraction time can lead to degradation of the pectin structure and decrease in functionality (Rezzadori et al., 2012; Saberian et al., 2017). Other innovative extractive techniques have been studied to recover pectin, such as ultrasound-assisted heating extraction, (Wang et al., 2015), ohmic heating (Saberian et al., 2017), ultra-high pressure (Guo et al., 2012), microwaveassisted extraction (Bagherian et al., 2011), or the use of electric fields (De Oliveira et al., 2015).

Lycopene, which is an important carotenoid with antioxidant properties, has been extracted from tomato pomace and tomato peel using solvent extraction with hexane, ethyl acetate, and ethanol with a yield ranging between 5 (using ethanol) and $120 \mathrm{mg} / 100 \mathrm{~g}$ (using ethyl acetate) (Calvo et al., 2007). However, due to all the environmental implications of using organic solvents, other technologies have been suggested and successfully applied for the extraction of lycopene. Among these technologies, supercritical $\mathrm{CO}_{2}$ extraction is suggested as a sustainable alternative, which leads to comparable extraction yields than the ones obtained with conventional solvent extraction. Topal et al. (2006) and Kehili et al. (2017) evaluated different operating conditions, 
temperature, and pressure, using supercritical $\mathrm{CO}_{2}$ extraction on tomato peel. The authors obtained 94 and $57 \%$ yield of total carotenoids, respectively, using this emerging technique.

Essential oils from citrus fruits have been extracted from the citrus peel by several physical-chemical, mechanical, and thermal techniques, such as cold pressing, solvent extraction, steam distillation, and microwave-assisted extraction (Mahato et al., 2019). Ferhat et al. (2007) extracted essential oils from lemon peels using cold pressing, hydrodistillation, and microwave-accelerated distillation. In hydrodistillation, the plant material is packed and water is added (sufficient amount) and brought to boil. Steam is then introduced and contacted with the plant material and the water; this generates the release of the plant components by hydrodiffusion and hydrolysis. Microwave-accelerated distillation consists on placing the plant material in a microwave reactor and heat it. The internal water in the plant material is then released carrying the essential oils which are then condensed in a condenser outside the reactor (Ferhat et al., 2007). The findings from Ferhat et al. (2007) indicate that microwave-accelerated distillation (MAD) shows comparable yields with hydrodistillation, with a much shorter extraction time (6 times lower). In addition, better antimicrobial activities for oils extracted by MAD were assessed against yeast and gram-negative bacteria, and it is considered and environmentally friendly technique.

Another extraction technique involves the degradation of the cell wall using enzymes. Stoll et al. (2003) developed a process using enzymatic hydrolysis of carrot pomace to recover carotene-rich hydrolysate that can be used as a functional ingredient in, e.g., model beverages (based on apple juice). The process consisted of the application of an enzyme mixture of cellulase and pectinase (cellulolytic and pectolytic activities) to degrade the cell wall of the carrot pomace after milling of this residue. Optimization of the hydrolysis step was the main aspect of the study by Stoll et al. (2003), which was successfully implemented at pilot scale $(10 \mathrm{~L})$. The conditions applied in the pilot run were $\mathrm{pH} 4.0,50^{\circ} \mathrm{C}$, enzyme combination corresponding to $750 \mathrm{ppm}$ of Pectinex Ultra SP-L (Novo Nordisk Ferment), and 750 ppm of Cytolase CL (DSM Food Specialties). The obtained hydrolysate corresponds to $64 \mathrm{mg}$ total carotene per kilogram of hydrolysate. Another wellknown application of enzymes is for the hydrolysis of lignocellulosic residues (e.g., sugarcane bagasse) into sugars and later conversion into second-generation ethanol. For this enzymatic reaction, a pretreatment step is required to facilitate the enzyme accessibility to cellulose and hemicellulose presented in the lignocellulosic residues (Mussatto et al., 2010).

Many studies have evaluated protein extraction from agrifood residues. Contreras et al. (2019) provide an excellent review on protein extraction from different agri-food residues, reviewing solvent and aqueous extraction (at alkaline, neutral, and acid conditions), biochemical extraction using enzymes, and physical and physical-chemical methods under dry and non-dry conditions. Regarding protein extraction, it seems that alkaline extraction provides higher yields (up to 95\%); however, this method is not selective, so other components such as polyphenols, hemicellulose, and lignin can be co-extracted. Sari et al. (2015) evaluate the protein extraction yield, at alkaline conditions, of different agri-food residues (rapeseed meal, sunflower meal, soybean meal, soybean hull, malt byproducts, among others). The authors identified that biomass composition affects the extraction yield, finding that cellulose and oil can significantly affect the extraction performance. When chemical extraction is low, the use of enzymeassisted processes might improve protein extraction. For instance, the use of carbohydrate degrading enzymes (cellulase, hemicellulase, xylanase, arabanase, and glucanase) might benefit from the release of proteins from the plant-based matrixes, as they can degrade the cellulose and hemicellulose from the cell wall (Contreras et al., 2019). The use of enzymes can be combined with neutral conditions, preventing the formation of protein-polyphenols complexes and also maintaining the functional properties of the proteins (Fetzer et al., 2018).

As previously mentioned, many valuable compounds are co-extracted and, depending on the application, can be further purified. The following section will outline purification technologies for further separation of valuable compounds mainly in aqueous plant-based extracts.

\section{Purification of Valuable Compounds from Plant-Based Extracts}

Separation and purification of the valuable components from a plant-based extract can be done using different (conventional and emerging) purification techniques such as adsorption, precipitation or crystallization, membrane separation, aqueous two-phase system separation (ATPS) (Galanakis, 2012), or combinations of these technologies. Adsorption is a promising technology able to purify complex mixtures (plant-based extracts) and also can be operated at mild conditions. Mild operation is often desired in food processing as thermal technologies can generate undesired flavors and change the organoleptic properties of the final products. In addition, adsorption can be a selective process when appropriate adsorbents (polymeric resins, zeolites, activated carbon) are used for capturing the target molecules (products or impurities).

\section{Protein Purification}

Proteins from vegetable sources are composed of storage proteins (globulin and albumins), structural proteins (ribosomal, membrane proteins), and biological active proteins (lectins) (González-Pérez \& Arellano, 2009). Pulses, oilseeds, and vegetables sources are rich in proteins (Fig. 2). Particularly, 
oilseed meals are rich protein sources accounting to up to $40 \%$ dry matter.

Oilseed proteins have been successfully purified by different techniques such as isoelectric precipitation (Akbari \& Wu, 2015; Ghodsvali et al., 2005; Karaca et al., 2011; Thiel et al., 2015; Xu \& Diosady, 2002) and adsorption (Marshall, 1990; Sewekow et al., 2008; Chung et al., 2005; Bérot et al., 2005; Zhang \& Glatz, 1999), being the former one the most applied (González-Pérez \& Arellano, 2009). Both techniques are often combined with membrane separation to increase purity. Isoelectric precipitation has been additionally applied in the manufacturing of pulse proteins, after milling of the sources to produce protein-rich flour (Boye et al., 2010). Ultrafiltration can be used to separate proteins (large molecules) from nutraceutical (small molecules, e.g., polyphenols, sugars, lipids) and antinutritional compounds (phytic acid).

Akbari and $\mathrm{Wu}$ (2015) purified napin and cruciferin (storage proteins) from rapeseed meal extract by isoelectric precipitation of cruciferin and subsequent napin purification by removing phytic acid, glucosinolates, and phenolic acids using ultrafiltration $(10 \mathrm{kDa})$ and diafiltration, obtaining a total yield of $52 \%$ while successfully removing higher than $80 \%$ of phytic and phenolic acids. Similarly, Xu and Diosady (2002) and Ghodsvali et al. (2005) successfully purified canola proteins using ultrafiltration and diafiltration before and after isoelectric precipitation of cruciferin fraction. Even though precipitation is widely applied, it has some disadvantages as it can affect the functional properties of the proteins such as solubility and additionally promotes aggregation (González-Pérez \& Arellano, 2009). Therefore, the use of mild conditions and technologies such as adsorption could benefit the functionality of the proteins.

Oilseed proteins have been successfully purified by adsorption, decreasing denaturalization and obtaining higher purities. Chung et al. (2005) purified the globulin fraction from flaxseed meal using the weak anion exchanger DEAE (diethylaminoethyl) Sephacel, at basic $\mathrm{pH}(\mathrm{pH} \mathrm{8.6)}$ and mid salt conditions recovering $63 \%$ of the total protein content in the meal with high purity. Interestingly, the authors only focused on the recovery of the globulin fraction while an additional minor peak is observed in the chromatogram. This flow through peak corresponded to around $30 \%$ of the protein content, which might represent the albumin fraction. Bérot et al. (2005) proposed to purify both protein fractions (albumins and globulins) from rapeseed meal extract using a combination of adsorptive steps. The author used the cation exchange resin, Source $30 \mathrm{~S}$, to capture napin and lipid proteins while cruciferin flow through. Cruciferin is subsequently polished by size exclusion (Sephacryl S-300) and napin is polished by HIC (hydrophobic interaction chromatography, Phenyl Sepharose 6 Fast Flow). After polishing both proteins, polyphenols and other antinutritional compounds were removed by dialysis. Purities greater $>99 \%$ were obtained for both proteins.

\section{Polyphenol Purification}

Polyphenol has been purified from the plant-based extract or fermentation broth by means of membrane separation, liquidliquid extraction (Silva et al., 2018b), preferential crystallization (Silva et al., 2018c), and adsorption (Moreno-González et al., 2020; Sevillano et al., 2014; Silva et al., 2018a; Soto et al., 2011)

Silva et al. (2018b) evaluated the used of liquid-liquid extraction to purify polyphenols from fermentation broth. As one of the critical factors to design a liquid-liquid extraction process is solvent selection, the authors suggested the use of the NRTL-SAC (Nonrandom Two-Liquid Segment Activity Coefficient) thermodynamic model. This model considers the excess entropy and enthalpy to determine the activity coefficient. The NRTL-SAC characterizes any molecule by using four molecular descriptors. The molecular descriptors represent the molecular surface characteristics of the solvent and solute molecules. These descriptors denote hydrophobicity $(\mathrm{X})$, polarity $\left(\mathrm{Y}^{+}\right.$and $\left.\mathrm{Y}^{-}\right)$, and hydrophilicity $(\mathrm{Z})$ (Chen \& Song, 2004). The authors, Silva et al. (2018b), use the NRTL-SAC model to predict partitioning into different solvents. The authors suggested different process configurations to purify polyphenols with similar characteristics. In another study, Silva et al. (2018c) used preferential crystallization (commonly used for enantiomer purification) to separate naringenin and trans-resveratrol (chemically related polyphenols). This study showed an alternative technique besides adsorption for recovering similar compounds; however, the solution needs to be concentrated and cooled to induce supersaturation and later crystallization.

Adsorption has been widely applied for recovery of phenolic compounds from liquid food streams. The studies performed by Pickardt et al. (2015) and Weisz et al. (2010) evaluated the adsorption of phenolics onto a polymeric resin and an ion exchange resin (XAD16 and Lewatit S 6328) using sunflower meal extract. Both studies aimed to recover proteins; however, they suggested the co-recovery of polyphenols compounds as a possibility to improve economic potential of the process. Thiel et al. (2015) evaluated the recovery of proteins, sinapic acid, and phytic acid from rapeseed meal extract. After extraction, purification was assessed with two processes using a $\beta$-zeolite in the $\mathrm{H}^{+}$form $\left(\mathrm{SiO}_{2} / \mathrm{Al}_{2} \mathrm{O}_{3}\right.$ ratio of $\left.150: 1\right)$ and the anion exchanger Purolite A200. Both purification processes accomplished the separation of the three components of interest. Ferri et al. (2011) studied the recovery of hydroxycinnamic acids from olive mill wastewater, using a synthetic mixture of ten polyphenols, which are the most representative ones of this side stream. The authors of this work also used macroporous food grade resins and a weak anion 
exchanger (XAD4, XAD7, XAD16, IRA96, and ENV+). An overall of $90 \%$ polyphenol recovery was found when desorbing with ethanol. Similarly, Moreno-González et al. (2020) evaluated the recovery of sinapic acid from rapeseed meal extract using a model feed system. Adsorption of sinapic acid on the polymeric resin FPX66 resulted to be selective. They demonstrated that other components such as sugars, glucosinolates, and phytic acid (often presented in food matrixes) poorly interact with the resin which benefits sinapic acid capture. At last, Schieber et al. (2003) developed a process using apple pomace extract to recover polyphenols and pectin. Phenolics are purified by adsorption on XAD16 and subsequently eluted using methanol. Solvent was evaporated and polyphenols were freeze dried.

\section{Polysaccharides Purification}

Pectin purification from citrus and fruit extracts (peels and pomace) can be accomplished by solvent precipitation, ion exchange chromatography, and dialysis (Lampitt et al., 1947), among others technologies. Besides bioactive phenolics from apple pomace, Schieber et al. (2003) purified pectin by alcohol precipitation of the pectin-containing effluent from the adsorption column where phenolics were captured.

Solvent precipitation with ethanol was applied by Galanakis et al. (2010) to purify dietary fibers from olive mill wastewater. After concentration of the wastewater (3.5-fold) and subsequence liquid-liquid extraction using ethanol/acid and ethanol/water mixtures, dietary fibers were precipitated by an increase of ethanol concentration up to $85 \mathrm{~mL} / 100 \mathrm{~mL}$. Precipitated fibers were deflated with acetone and dried. As mentioned earlier, olive mill wastewater also contains significant amount of polyphenols. The suggested purification process by the authors allows the co-recovery of dietary fibers and polyphenols. As the fibers precipitate in ethanol, phenolics are soluble in this solvent. The recovered dietary fiber was further characterized, finding that the soluble fraction is rich on pectin polysaccharides while the insoluble fraction is rich of glucose, xylose, galacturonic acid, and rhamnose.

Ion exchange chromatography has been successfully implemented for sucrose purification from beet molasses (Ganetsos \& Barker, 1992) and separation of fructose and glucose (Azevedo \& Rodrigues, 2001; Hashimoto, 1983, 1987). Chilamkurthi et al. (2012) assessed the different cation exchangers in the form of $\mathrm{Na}^{+}, \mathrm{H}^{+}, \mathrm{K}^{+}$, and $\mathrm{Ca}^{2+}$, to evaluate the separation of arabinose and sugars. The model components used in this study were galactose, glucose, arabinose, lactose, and sugar acid. Their findings indicate that appropriate separation of the different components is accomplished using the cation exchangers in the form of $\mathrm{Ca}^{2+}$ and $\mathrm{K}^{+}$.

Another purification method for polysaccharides like sugars, glucose, is crystallization. As crystallization occurs when the solution is supersaturated, a pre-concentration is required. The shape and size of crystal will determine the subsequence steps to separate them from their mother liquids. These steps will involve filtration and drying (Berk, 2013a).

\section{Flavor Ingredients Recovery/Purification}

Natural flavors, which are generally obtained from plant or animal sources, are widely used in the food sector mainly in beverages. Saffarionpour and Ottens (2018) provide an excellent review on the different technologies applied for purifying these types of products, including distillation, pervaporation, and adsorption.

Additionally, adsorption has been applied for capturing of impurities (e.g., off-flavors) instead of the valuable products. Gernat et al. (2020) successfully decreased the concentration of wort off-flavors (2-methylbutanal, 3-methylbutanal, methional, 2-methylpropanal, and furfural) in alcohol-free beer using zeolites at pilot scale $(150 \mathrm{~L})$. The authors evaluated other adsorbents such as polymeric resins; however, it was proved that resins are able to adsorb other flavor components, affecting the quality of the final product, as the aim was only to remove wort flavors. Off-flavor components are mainly composed of hydrophobic organic molecules (aldehydes, ketones, carboxylic acids). The results from Gernat et al. (2020) introduced the possibility of removing these components from food liquid streams by using zeolites to increase selectivity to aldehydes or by using hydrophobic resins for overall off-flavors removal.

\section{Final Product Formation}

The last step toward the manufacturing of a product from a side stream of a food process corresponds to formulation, defined here as the ultimate product form (emulsions, powders, pieces, liquid, among others).

\section{Food Powders/Solid Extracts}

Drying technology is mostly used for food preservation, as minimization of moisture content in food products inhibits microbial growth. However, drying can also be used to improve the physical properties of a product (Smith, 2011), for instance, spray drying is used to dry liquid food and form a powder product. Among the different types for dryers utilize by food industry, pneumatic drying, spray drying, drum drying, tray drying, and freeze drying are applied in formulation.

Spray drying has been applied to concentrate food liquids such as coffee, milk, and juices. This technique is also used for encapsulation of food ingredient, such as flavors and whole food substances (e.g., chocolate), where materials can be encapsulated as single particle structure (ingredient surrounded by a matrix wall) or in an aggregate structure (ingredient particles fixed in a matrix) (Desai \& Jin Park, 2005). One of the main 
advantages of spray drying is that it produces a stable particulate solid product from a liquid in a one continuous step. However, wall matrix materials are limited, being the most applied maltodextrins, hydrophobically modified starch, gum acacia (Desai \& Jin Park, 2005), whey, gelatin and sucrose (Anandharamakrishnan \& Ishwarya, 2015). Spray drying seems to be a suitable technique in the final formulation of a product from a side stream of food (plant extract, wastewater) as these streams are mainly liquid streams. In addition, spray drying is relatively economical and suitable for heat-sensitive materials (Anandharamakrishnan \& Ishwarya, 2015).

Freeze drying is mostly applied in the pharmaceutical field and also in the production of expensive biological products when product quality is the most important attribute of the product. Its application in the food sector for the recovery of products might be limited to high-value products such as proteins, enzymes, and heat-sensitive products as flavors. The principle consists on freezing the feed on a chamber where vacuum is applied. Dehydration occurs by sublimation, mostly of water which is recovered by mechanical vacuum pumps (Barbosa-Cánovas et al., 2005). Note that freeze drying is usually operated in batch mode, as it requires of a drying chamber where the product is frozen and longer drying times than other techniques such as spray and drum drying, which limits its application to small throughputs. The product form obtained from freeze drying is pieces, which are usually grounded after processing (Barbosa-Cánovas et al., 2005).

Desobry et al. (1997) evaluated the drying process of $\beta$ carotene encapsulation using freeze drying, spray drying, and drum drying. The authors demonstrated that the characteristics of the dried $\beta$-carotene obtained from drum drying possess similar characteristics than the one obtained with the other two methods. In addition, during storage, the authors identified that drum drying gave higher product retention comparing to the other two methods. The solid obtained in the shape of sheets can be grounded to different particle sizes.

Other types of dryers that can be used for product formulations are tray dryers, bin dryers, rotatory dryers, and pneumatic dryers. Particularly these dryers are used (but not limited) when the feeds stream is composed of solids (particulate, grains, granulated materials, precipitates, or crystals). Bin and tray dryers are operated in batch mode while rotatory and pneumatic dryers can be operated in continuous mode (Berk, 2013b).

Selection of drying technique will highly depend on the desired product characteristics and the processing volume.

\section{Food Byproducts Processing Examples}

As previously mentioned, the recovery and purification of valuable compounds from food side streams (bran, wastewater, oilseed meal, fruit pomace, among others) is dictated by the products to be recovered and the nature of the source material. In the following paragraphs, examples of purification processes are described based on the previously discussed techniques and literature.

Galanakis et al. (2010) co-recovered dietary fiber from olive mill wastewater (Fig. 4a). The suggested process consisted in a pre-concentration step of the wastewater, which might help to increase the extraction yield. Valuable compounds were extracted from the wastewater using ethanol by adding $5 \mathrm{~mL}$ of ethanol and $1 \mathrm{~g}$ of citric acid and completed $100 \mathrm{~mL}$ of mixture with the concentrated wastewater. Extraction was done at $80^{\circ} \mathrm{C}$ for 10 minutes. Dietary fiber was precipitated by contacting the extraction mixture in $95 \%(\mathrm{v} / \mathrm{v})$ ethanol up to a concentration of $85 \%(\mathrm{v} / \mathrm{v})$ and boiled for 10 minutes. Precipitated dietary fiber was filtrated and washed with acetone and chloroform to remove remained oil and dried for further analysis. The discarded liquid from the precipitation is rich in polyphenols. The authors found a concentration of $1.25 \mathrm{~g} / \mathrm{L}$ which is similar to the concentration of phenolics found in extra virgin oil. The phenolic rich fraction might contain different types of phenolic compounds, mainly hydroxycinnamic acids. These phenolic compounds could be further separated from the liquid by crystallization and dried as suggested by Silva et al. (2018b). Recovery of solvents could be accomplished by distillation and can be recycled to the extraction system which might additionally benefit process economics.

When using oilseed meals as byproducts, proteins, dietary fibers, and polyphenols could be purified. Aqueous extraction assisted with salt could be applied as an alternative method, instead of solvent extraction or alkaline extraction. Separation of small molecules (sugars and polyphenols) from the large molecules (proteins) can be accomplished using membranes (Ghodsvali et al., 2005; Xu \& Diosady, 2002). Isolate of both proteins could be further processed by further membrane concentration and freeze drying; however, each protein has specific applications. Napin is a basic protein stable at a wide $\mathrm{pH}$ range and holds foaming properties while cruciferin possesses emulsifying, gelling, and binding properties (Aider \& Barbana, 2011; Wanasundara et al., 2016). Purification of both proteins by ion exchange chromatography has been suggested (Moreno-González et al. (submitted manuscript)), where napin is bound to the resin while cruciferin flow through. The purified protein fractions after chromatography can be sent to another membrane unit to remove buffer salts and dried. The permeate, from the small molecules' separation, contains the remained co-extracted components, polyphenols, sugars, phytic acids, and glucosinolates. MorenoGonzález et al. (2020) suggested capturing the polyphenols compounds using a food grade macroporous resin (FPX66). The authors demonstrated that the other components, sugar, phytic acid, and glucosinolates poorly interact with the resin. The obtained sinapic acid (mayor phenolic in rapeseed meal) 
a

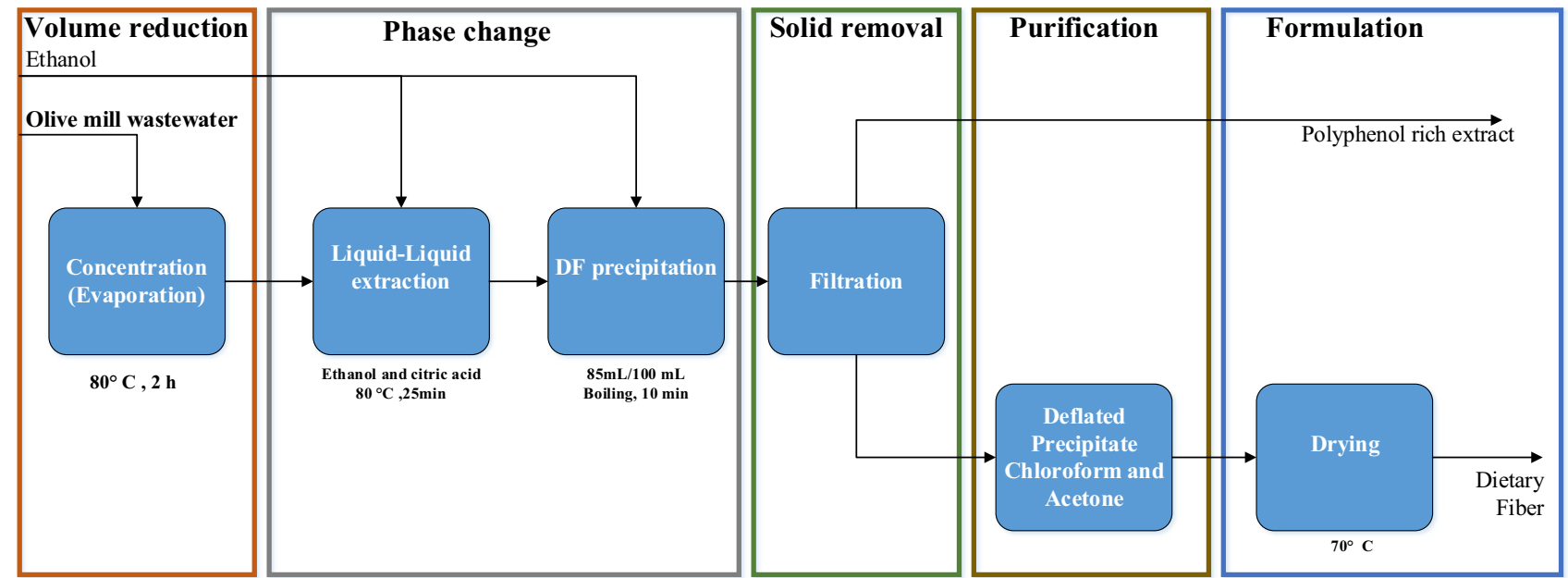

b

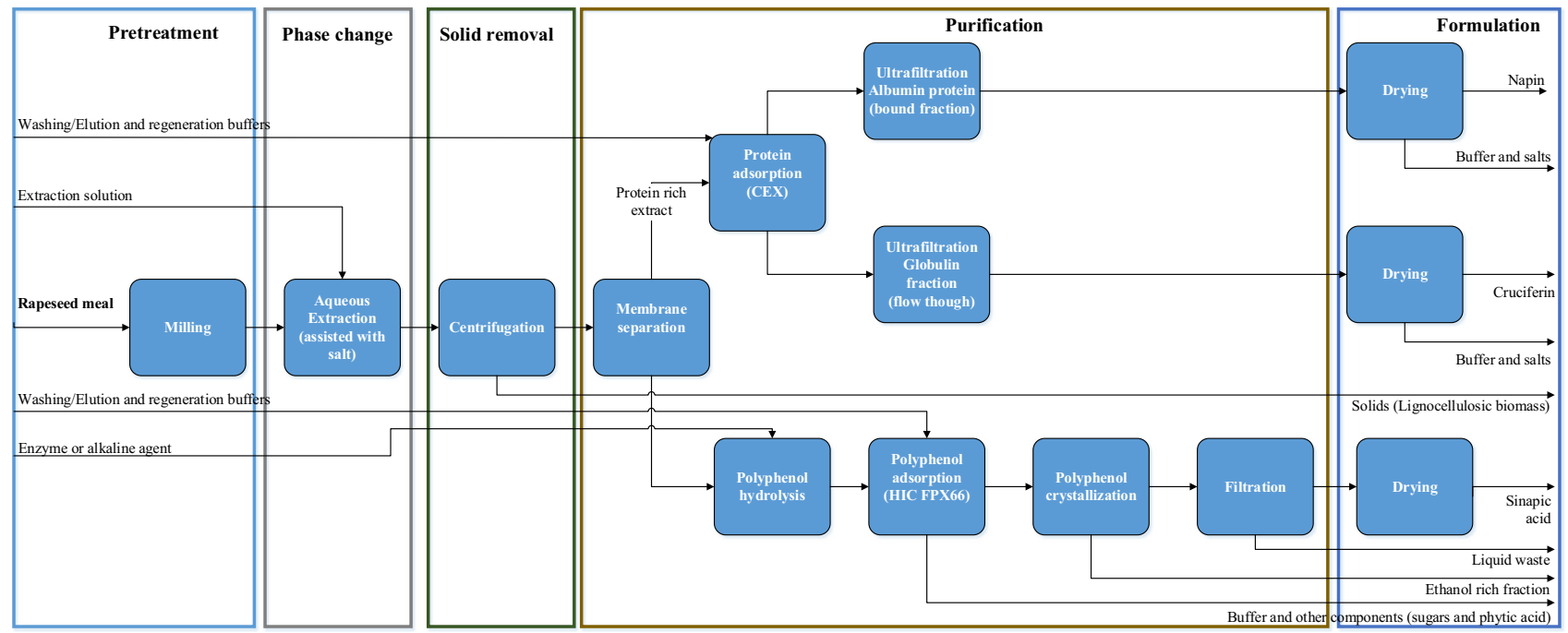

Fig. 4 Process purification of different valuable compounds from food stream byproducts, a olive mill wastewater and $\mathbf{b}$ rapeseed meal

fraction, recovered using ethanol/water mixture (Ferri et al., 2011; Moreno-González et al., 2020; Silva et al., 2018a), could be crystallized (Silva et al., 2018b), washed, and dried (Fig. 4b). As with the previous example, solvent could be additionally recovered by distillation. The flow through fraction from the adsorption column contains sugars, phytic acid, and glucosinolates. Phytic acid is well known as an antinutrient compound due to its ability to bind to mineral ions such as magnesium and calcium, therefore is often removed from food products. However, sugars are valuable compounds and further purification of sugars could be accomplished by chemical precipitation of phytic acid. The remained solid fraction from the aqueous extraction is rich in dietary fibers hemicellulose, cellulose, and lignin, which could additionally be processed to obtain reducing sugars for biofuels.

Following some of the strategies suggested previously, processing of fruit/tuber pomace (Fig. 5a) could start with the acid extraction of the polyphenols and soluble carbohydrates, which was applied for apple pomace by Schieber et al. (2003) and could be extended to other type of pomace such as carrot or tomato. The extract contains polyphenol components and soluble sugars which could be purified by adsorption using food grade hydrophobic polymeric resins such as XAD16 and FPX66 as soluble sugars might poorly interact with the hydrophobic matrixes (Ferri et al., 2011; Moreno-González et al., 2020; Schieber et al., 2003). After polyphenol elution, Schieber et al. (2003) recommended to evaporate the solvent, which could be recovered by distillation and remove the remained water by freeze drying. Among the polyphenols that could be potentially recovered, there is lycopene from tomato pomace (Lu et al., 2019), carotene from carrot pomace (Stoll et al., 2003), and phloridzin and chlorogenic acid from apple pomace (Schieber et al., 2003). The flow through obtained liquid from the adsorption 
a

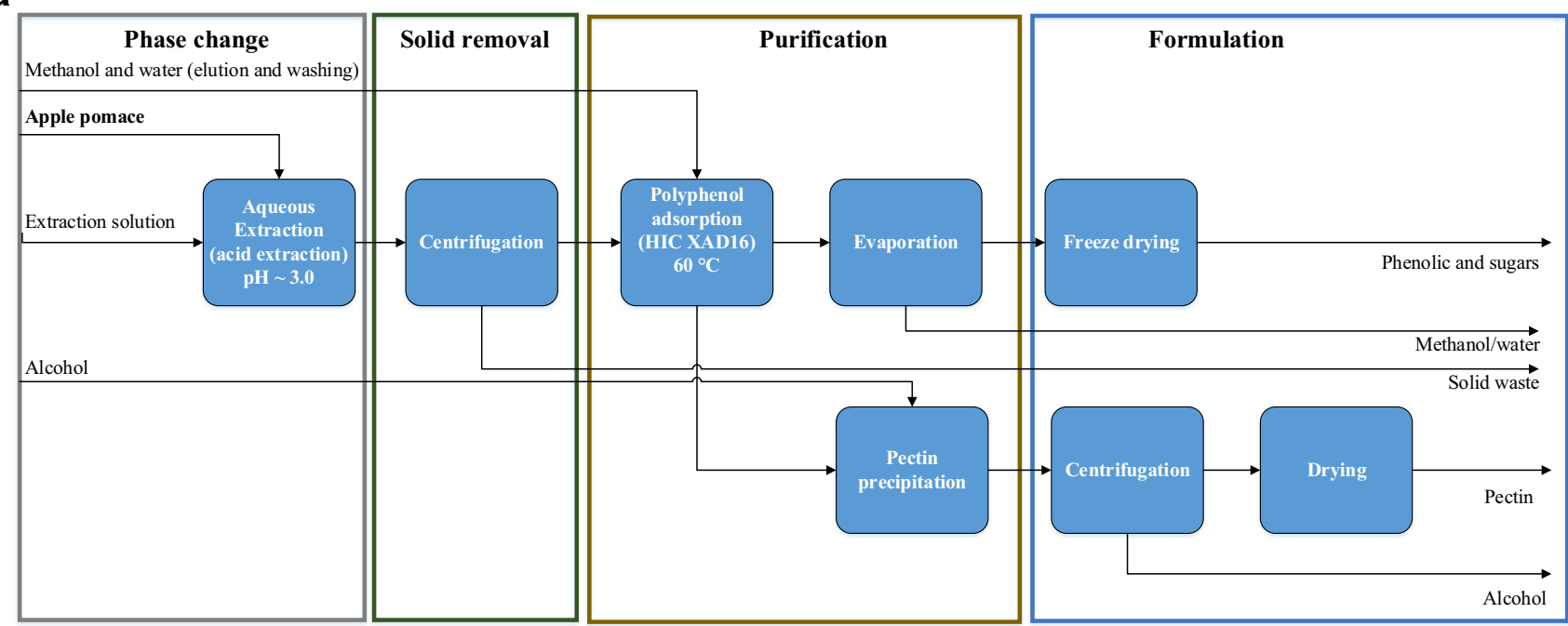

b



Fig. 5 Process purification of different valuable compounds from food stream byproducts, a apple pomace and $\mathbf{b}$ cereal bran

is rich in pectin, which can be purified by alcohol precipitation, filtrated or centrifuged, to remove liquid, and finally dried.

Lignocellulosic biomasses from food byproducts such as cereal bran could be processed to recover antioxidants (polyphenols), proteins, and fermentable sugars (Fig. 5b). As previously mentioned, cereal brans are rich on phenolics and dietary fibers. Aqueous extraction (alkaline or acid) of proteins and polyphenols is then performed. Note that alkaline conditions could oxidize the phenolic compounds or form protein-polyphenols complexes; milder conditions, like neutral extraction, are therefore preferred. Solid-liquid separation between the extract and the insoluble fiber can be done by centrifugation of filtration. Purification of the plant-based extract can be done by isoelectric protein precipitation as recommended by Celiktas et al. (2014), and polyphenols could be further purified by adsorption (hydrophobic polymeric resins) (Ferri et al., 2011; Moreno-González et al., 2020; Schieber et al., 2003; Silva et al., 2018a). The protein precipitate could be filtrated and dried while phenolics could be crystallized and dried. The solid fraction from the aqueous extraction could be further treated by liquid hot water pretreatment for autohydrolysis of hemicellulose followed by the hydrolysis of the plant fibers using enzymes to produce fermentable sugars that can be later converted into biofuels or other biochemicals.

\section{Economic Considerations}

This work has extensively discussed the technical feasibility of recovering valuable compounds from food side streams. 
However, for large-scale implementation, economic feasibility is as important as technological potential.

Economic considerations include three main factors: (1) estimation of capital investment, (2) operating cost, and (3) profitability analysis. These factors can be assessed using well-known methodologies described elsewhere (Harrison et al., 2015; Seider et al., 2010; Towler \& Sinnott, 2013). Regarding capital investment, one of the main considerations is the cost of the land when new facilities are built. Therefore, careful considerations, such as proximity to the facilities where the side stream is generated, should be taken into account. Proximity or even installing new equipment in the facilities will consequently reduce transportation cost and therefore increase economic potential. Moreover, the aim is to have low CAPEX (capital expenditure) and OPEX (operating cost).

Knowing that voluminous streams are typically produced in the food sectors, recovery and purification of the valuable compounds seems to be an attractive option that can substitute the cost associated to their disposal which would potentially be economically favorable, as, when treated in the same facilities, might reduce raw material costs (operating cost). In addition, minimization of additional waste streams should also be considered by recovering several multiple products from a single stream. Furthermore, this might benefit economic feasibility as more products could be sold, reducing or even removing the cost associated to them when treated as waste.

Moreover, implementation of continuous operation (often desired by the food sector) and counter current operation might lead to more efficient operation and cost reductions. In terms of CAPEX, this might lead to smaller equipment, while for OPEX, considering as an example, continuous chromatography, this might reduce buffer consumption and adsorbent cost (Steinebach et al., 2016). Semicontinuous chromatography such as simulated moving bed (SMB) has shown great potential in different industry fields, such as petrochemical, pharmaceutical, biopharmaceutical, and food (Ganetsos \& Barker, 1993).

At last, it is important to consider that the selling cost of the products (profitability analysis) should be competitive with the market and process considerations such as process intensification and heat integration should be carefully assessed during process design.

Techno-economic evaluation (TEE) combined with life cycle assessment (LCA) has been suggested to assess biorefineries (Brown et al., 2014). This combination is also applicable to assessing the processing of food side streams to recover valuable products. LCA estimates the environmental impact associated to process operation, from raw materials to disposal and/or recycle, while TEE assesses technical feasibility and economic potential. By combining both assessments, the findings of each discipline are enhanced (Brown et al., 2014) which might help on decision-making to mitigate harmful environmental implications of processing food side streams.

\section{Future Prospects}

Multiple valuable products can be recovered from a single food side stream depending on the selected processing steps and the source origin (strong, soft, and wastewater). Technology Readiness Level (TRL) Index, introduced by NASA (Héder, 2017), can be used to assess the stage toward large-scale implementation where certain technology is located. The TRL index scale goes from 1 to 9 , where TRL 1 concerns to fundamental concept/research, TRL 2-4 to technological research, TRL 5-8 to product demonstration, and TRL 9 to implementation (Roque et al., 2020).

For processing lignocellulosic biomass (strong structures), selection of a suitable extraction technique is crucial in order to recover several products. Different extraction techniques can affect the properties of the products to be recovered. Even though alkaline extraction is the most reported method, it also could promote protein denaturation and phenolic acid oxidation, which consequently reduce product yield and quality. Even though extraction is a well-established technology (TRL 9), the use of milder conditions such as neutral extraction, other extraction systems such as aqueous two-phase systems (ATPS), or alternative techniques such as supercritical $\mathrm{CO}_{2}$ (TRL 5-8) should be further studied and optimized for this step. However, this implicates higher R\&D associated cost and these technologies are not yet implemented in large scale.

Among other separation techniques, adsorption is an attractive alternative for capturing of valuable products such as proteins and polyphenols due to its simplicity, high efficiency, ease to scale up, and selectivity when appropriate adsorbents are available. Particularly for polyphenols adsorption, it has been demonstrated that food grade polymeric resins (e.g., XAD16, FPX66 from the Amberlite series) are highly effective. Often elution of the bound compounds concentrates them which facilitate their further processing by crystallization/ precipitation and drying. Adsorption could also be used for removal of unwanted compounds in a liquid stream such as off-flavors (Gernat et al., 2020) and colorants, as already applied for de-bittering of fruit juices. Even though packed bed chromatography is a well-established technology (TRL 9), better understanding of the interactions between the adsorbent and the bound components might accelerate the implementation of more adsorptive processes in the food sector. Moreover, and as previously mentioned, continuous operation (TLR 5-8), not only with SMB systems (simulated moving bed systems) but with emerging systems such as periodic countercurrent chromatography (PCC), might benefit technologic and economic potential. 
Fruits and vegetables residues (soft structures) are low in protein content but rich in polyphenols and carbohydrates such as pectin. As with the residues from cereal, oilseed, and pulses, extraction methods will greatly influence the following purification steps. Alcohol extraction is a very effective technique for polyphenols as it utilizes the higher solubility of these types of components in alcohols. Even though solvents could be recovered by distillation, the environmental implications that they represent encourage the need of utilized alternative extraction techniques. Great progress has been accomplished with supercritical fluid extraction, which additionally provides selectivity toward the extracted compounds (Saffarionpour \& Ottens, 2018). However, large-scale implementation has not been fully established and more effort is needed in order to guarantee safety during operation.

The last stage of the processing will be related to the ultimate product form, which commonly is a solid form. Therefore, water of other solvents should be additionally removed by drying. Spray drying, drum drying, and freeze drying are the few drying technologies able to dry liquid streams.

This work describes a structure approach of the different process steps required to recover multiple value-added compounds from a single agri-food streams. This approach combined with TEE, LCA, and TRL might facilitate process design of new food side streams. Recovered components with high purity level can be applied in pharmaceutical and cosmetic sectors. For the food sector, where functionality (emulsification, gelling formation, thickening, viscosity) is given by combining several ingredients, high degree of purity might not be needed. Limited studies are available (Geerts et al., 2017; Karefyllakis et al., 2019; Kornet et al., 2020), exploring this new way of thinking, and they have shown that the properties of the final products are not significantly changed.

\section{Concluding Remarks}

This review presents a structure approach of the different process steps required to recover valuable components from food side streams. It demonstrates that a multitude of valuable compounds can be recovered from a single side stream including, in most of the cases, polyphenols, carbohydrates (dietary fibers), and proteins. The recovery of multiple products depends on the source origin (strong and soft matrixes and wastewater).

It is clear that to fully isolate the extracted compounds, several separation technologies will be combined and a detailed life cycle assessment (LCA) and techno-economic evaluation (TEE) should be performed to evaluate feasibility and profitability.

As previously mentioned, the application of the different technologies will depend on their level of technological readiness to large-scale implementation (TRL) and its suitability to continuous operation. Moreover, the processing of plantbased side streams should be cost-effective, and keeping the functionality of the products (e.g., nutritional value of proteins and antioxidant activity in polyphenols) in order to be successfully applied in pharmaceutical, cosmetic, and food products. The presented approach might improve the valorization of industrial food side streams which could be beneficial in terms of sustainability.

Funding This work was supported by the ISPT (Institute for Sustainable Process Technology) under the project CM-20-07 in adsorption of nonvolatiles from food products. Thanks to the industrial partners DSM, Unilever, Friesland Campina, and Royal Cosun for their valuable input throughout the project.

Open Access This article is licensed under a Creative Commons Attribution 4.0 International License, which permits use, sharing, adaptation, distribution and reproduction in any medium or format, as long as you give appropriate credit to the original author(s) and the source, provide a link to the Creative Commons licence, and indicate if changes were made. The images or other third party material in this article are included in the article's Creative Commons licence, unless indicated otherwise in a credit line to the material. If material is not included in the article's Creative Commons licence and your intended use is not permitted by statutory regulation or exceeds the permitted use, you will need to obtain permission directly from the copyright holder. To view a copy of this licence, visit http://creativecommons.org/licenses/by/4.0/.

\section{References}

Agbor, V. B., Cicek, N., Sparling, R., Berlin, A., \& Levin, D. B. (2011). Biomass pretreatment: Fundamentals toward application. Biotechnology Advances, 29(6), 675-685. https://doi.org/10.1016/ j.biotechadv.2011.05.005.

Ahmad, F., Pasha, I., Saeed, M., \& Asgher, M. (2019). Antioxidant profiling of native and modified cereal brans. 54(4), 1206-1214. https:// doi.org/10.1111/ijfs.14046.

Aider, M., \& Barbana, C. (2011). Canola proteins: composition, extraction, functional properties, bioactivity, applications as a food ingredient and allergenicity - A practical and critical review. Trends in Food Science \& Technology, 22(1), 21-39. https://doi.org/10.1016/ j.tifs.2010.11.002.

Akbari, A., \& Wu, J. (2015). An integrated method of isolating napin and cruciferin from defatted canola meal. LWT - Food Science and Technology, 64(1), 308-315. https://doi.org/10.1016/j.lwt.2015.05. 046.

Almeida-Rivera, C., Bongers, P., \& Zondervan, E. (2016). Chapter 15 - A structured approach for product-driven process synthesis in foods manufacture. In M. Martín, M. R. Eden, \& N. G. Chemmangattuvalappil (Eds.), Computer Aided Chemical Engineering (Vol. 39, pp. 417-441). Elsevier.

Anandharamakrishnan, C., \& Ishwarya, S. P. (2015). Introduction to encapsulation of food ingredients. In C. Anandharamakrishnan \& S. P. Ishwarya (Eds.), Spray Drying Techniques for Food Ingredient Encapsulation (pp. 37-64). John Wiley \& Sons, Incorporated.

Arapoglou, D., Varzakas, T., Vlyssides, A., \& Israilides, C. (2010). Ethanol production from potato peel waste (PPW). Waste Management, 30(10), 1898-1902. https://doi.org/10.1016/j. wasman.2010.04.017. 
Aravantinos-Zafiris, G., Oreopoulou, V., Tzia, C., \& Thomopoulos, C. D. (1992). Utilisation of orange by-products - orange peel carotenoids. 59(1), 77-79. https://doi.org/10.1002/jsfa.2740590111.

Azevedo, D. C. S., \& Rodrigues, A. E. (2001). Fructose-glucose separation in a SMB pilot unit: Modeling, simulation, design, and operation. AICHE Journal, 47(9), 2042-2051. https://doi.org/10.1002/ aic.690470915.

Bagherian, H., Ashtiani, F. Z., Fouladitajar, A., \& Mohtashamy, M. (2011). Comparisons between conventional, microwave-and ultrasound-assisted methods for extraction of pectin from grapefruit. Chemical Engineering and Processing: Process Intensification, 50(11-12), 1237-1243.

Balandrán-Quintana, R. R., Mercado-Ruiz, J. N., \& Mendoza-Wilson, A. M. (2015). Wheat Bran Proteins: A Review of Their Uses and Potential. Food Reviews International, 31(3), 279-293. https://doi. org/10.1080/87559129.2015.1015137.

Barbosa-Cánovas, G. V., Ortega-Rivas, E., Juliano, P., \& Yan, H. (2005). Drying. In Food Powders: Physical Properties, Processing, and Functionality (pp. 271-304). Springer US.

Berk, Z. (2013a). Crystallization and Dissolution. In Z. Berk (Ed.), Food Process Engineering and Technology (pp. 353-371). Elsevier Science \& Technology.

Berk, Z. (2013b). Dehydration. In Food Process Engineering and Technology. Elsevier Science \& Technology.

Bérot, S., Compoint, J. P., Larré, C., Malabat, C., \& Guéguen, J. (2005). Large scale purification of rapeseed proteins (Brassica napus L.). Journal of Chromatography B, 818(1), 35-42. https://doi.org/10. 1016/j.jchromb.2004.08.001

Bongers, P. M. M., \& Almeida-Rivera, C. (2009). Product Driven Process Synthesis Methodology. In J. Jeżowski \& J. Thullie (Eds.), Computer Aided Chemical Engineering (Vol. 26, pp. 231236). Elsevier.

Bordiga, M., Travaglia, F., \& Locatelli, M. (2019). Valorisation of grape pomace: an approach that is increasingly reaching its maturity - a review. 54(4), 933-942. https://doi.org/10.1111/ijfs.14118.

Boye, J., Zare, F., \& Pletch, A. (2010). Pulse proteins: Processing, characterization, functional properties and applications in food and feed. Food Research International, 43(2), 414-431. https://doi.org/10. 1016/j.foodres.2009.09.003.

Brown, T. R., Wright, M. M., Román-Leshkov, Y., \& Brown, R. C. (2014). 2 - Techno-economic assessment (TEA) of advanced biochemical and thermochemical biorefineries. In K. Waldron (Ed.), Advances in Biorefineries (pp. 34-66). Woodhead Publishing.

Butnariu, M., \& Butu, A. (2015). Chemical Composition of Vegetables and Their Products. In P. C. K. Cheung \& B. M. Mehta (Eds.), Handbook of Food Chemistry (pp. 627-692). Springer Berlin Heidelberg.

Calvo, M. M., Dado, D., \& Santa-María, G. (2007). Influence of extraction with ethanol or ethyl acetate on the yield of lycopene, $\beta$-carotene, phytoene and phytofluene from tomato peel powder. European Food Research and Technology, 224(5), 567-571. https://doi.org/ 10.1007/s00217-006-0335-8.

Camire, M. E., Violette, D., Dougherty, M. P., \& McLaughlin, M. A. (1997). Potato Peel Dietary Fiber Composition: Effects of Peeling and Extrusion Cooking Processes. Journal of Agricultural and Food Chemistry, 45(4), 1404-1408. https://doi.org/10.1021/j9604293.

Capellini, M. C., Giacomini, V., Cuevas, M. S., \& Rodrigues, C. E. C. (2017). Rice bran oil extraction using alcoholic solvents: Physicochemical characterization of oil and protein fraction functionality. Industrial Crops and Products, 104, 133-143. https://doi. org/10.1016/j.indcrop.2017.04.017.

Carrillo-López, A., \& Yahia, E. M. (2019). Chapter 6 - Morphology and Anatomy. In E. M. Yahia (Ed.), Postharvest Physiology and Biochemistry of Fruits and Vegetables (pp. 113-130). Woodhead Publishing.
Celiktas, M. S., Kirsch, C., \& Smirnova, I. (2014). Cascade processing of wheat bran through a biorefinery approach. Energy Conversion and Management, 84, 633-639. https://doi.org/10.1016/j.enconman. 2014.04.039.

Chedea, V. S., Kefalas, P., \& Socaciu, C. (2010). Patterns of carotenoid pigments extracted from two orange peel wastes (Valencia and Navel var.). Journal of Food Biochemistry, 34(1), 101-110. https://doi.org/10.1111/j.1745-4514.2009.00267.x.

Chen, C.-C., \& Song, Y. (2004). Solubility Modeling with a Nonrandom Two-Liquid Segment Activity Coefficient Model. Industrial \& Engineering Chemistry Research, 43(26), 8354-8362.

Chilamkurthi, S., Willemsen, J.-H., van der Wielen, L. A. M., Poiesz, E., \& Ottens, M. (2012). High-throughput determination of adsorption equilibria for chromatographic oligosaccharide separations. Journal of Chromatography A, 1239, 22-34. https://doi.org/10.1016/j. chroma.2012.03.042.

Chung, M. W. Y., Lei, B., \& Li-Chan, E. C. Y. (2005). Isolation and structural characterization of the major protein fraction from NorMan flaxseed (Linum usitatissimum L.). Food Chemistry, 90(1), 271-279. https://doi.org/10.1016/j.foodchem.2003.07.038.

Contreras, M. d. M., Lama-Muñoz, A., Manuel Gutiérrez-Pérez, J., Espínola, F., Moya, M., \& Castro, E. (Eds.). (2019). Protein extraction from agri-food residues for integration in biorefinery: Potential techniques and current status. Bioresource Technology, 280, 459477. https://doi.org/10.1016/j.biortech.2019.02.040.

De Oliveira, C. F., Giordani, D., Gurak, P. D., Cladera-Olivera, F., \& Marczak, L. D. F. (2015). Extraction of pectin from passion fruit peel using moderate electric field and conventional heating extraction methods. Innovative Food Science \& Emerging Technologies, 29, 201-208.

Desai, K. G. H., \& Jin Park, H. (2005). Recent Developments in Microencapsulation of Food Ingredients. Drying Technology, 23(7), 1361-1394. https://doi.org/10.1081/DRT-200063478.

Desobry, S. A., Netto, F. M., \& Labuza, T. P. (1997). Comparison of Spray-drying, Drum-drying and Freeze-drying for $\beta$-Carotene Encapsulation and Preservation. Journal of Food Science, 62(6), 1158-1162. https://doi.org/10.1111/j.1365-2621.1997.tb12235.x.

Espina, L., Somolinos, M., Lorán, S., Conchello, P., García, D., \& Pagán, R. (2011). Chemical composition of commercial citrus fruit essential oils and evaluation of their antimicrobial activity acting alone or in combined processes. Food Control, 22(6), 896-902. https://doi.org/ 10.1016/j.foodcont.2010.11.021.

European Comission (2017). Circular Economy - European Comission https://ec.europa.eu/growth/industry/sustainability/circulareconomy_en. Accessed 11 Aug 2017.

European Commission (2011). Evolution Of (Bio-) Waste Generation/ Prevention And (Bio-) Waste Prevention Indicators http://ec.europa. eu/environment/waste/prevention/pdf/SR1008_FinalReport.pdf. Accessed 1 Sept 2017.

European Commission (2014). Impact assessment on measures addressing food waste to complete swd (2014) 207 regarding the review of eu waste management targets http://ec.europa.eu/environment/ eussd/pdf/IA.PDF. Accessed 1 Sept 2019.

Ferhat, M. A., Meklati, B. Y., \& Chemat, F. (2007). Comparison of different isolation methods of essential oil from Citrus fruits: cold pressing, hydrodistillation and microwave 'dry' distillation. 22(6), 494-504. https://doi.org/10.1002/ffj.1829.

Ferri, F., Bertin, L., Scoma, A., Marchetti, L., \& Fava, F. (2011). Recovery of low molecular weight phenols through solid-phase extraction. Chemical Engineering Journal, 166(3), 994-1001.

Fetzer, A., Herfellner, T., Stäbler, A., Menner, M., \& Eisner, P. (2018). Influence of process conditions during aqueous protein extraction upon yield from pre-pressed and cold-pressed rapeseed press cake. Industrial Crops and Products, 112, 236-246. https://doi.org/10. 1016/j.indcrop.2017.12.011. 
Fleddermann, M., Fechner, A., Rößler, A., Bähr, M., Pastor, A., Liebert, F., \& Jahreis, G. (2013). Nutritional evaluation of rapeseed protein compared to soy protein for quality, plasma amino acids, and nitrogen balance - A randomized cross-over intervention study in humans. Clinical Nutrition, 32(4), 519-526. https://doi.org/10. 1016/j.clnu.2012.11.005.

Food and Agriculture Organization of the United Nations (FAO) (2020). FAOSTAT Production Quantity http://www.fao.org/faostat/en/\# data/QC. Accessed 29 Apr 20202020.

Galanakis, C. M. (2012). Recovery of high added-value components from food wastes: Conventional, emerging technologies and commercialized applications. Trends in Food Science \& Technology, 26(2), 68-87. https://doi.org/10.1016/j.tifs.2012.03.003.

Galanakis, C. M. (2015) 3. The universal recovery strategy. In Food waste recovery - Processing technologies and industrial techniques. Elsevier.

Galanakis, C. M., Tornberg, E., \& Gekas, V. (2010). A study of the recovery of the dietary fibres from olive mill wastewater and the gelling ability of the soluble fibre fraction. LWT - Food Science and Technology, 43(7), 1009-1017. https://doi.org/10.1016/j.lwt. 2010.01.005.

Ganetsos, G., \& Barker, P. (1992). Developments in large-scale batch chromatography. In G. Ganetsos \& P. Barker (Eds.), Preparative and production scale chromatography (pp. 3-10).

Ganetsos, G., \& Barker, P. (1993). Semicontinuous countercurrent chromatography refiners. In G. Ganetsos \& P. E. Barker (Eds.), Preparative and production scale chromatography (pp. 233-255).

Geerts, M. E. J., Mienis, E., Nikiforidis, C. V., van der Padt, A., \& van der Goot, A. J. (2017). Mildly refined fractions of yellow peas show rich behaviour in thickened oil-in-water emulsions. Innovative Food Science \& Emerging Technologies, 41, 251-258. https://doi.org/ 10.1016/j.ifset.2017.03.009.

Gernat, D. C., Penning, M. M., Swinkels, F. M., Brouwer, E. R., \& Ottens, M. (2020). Selective off-flavor reduction by adsorption: A case study in alcohol-free beer. Food and Bioproducts Processing, 121,91-104. https://doi.org/10.1016/j.fbp.2019.12.007.

Ghodsvali, A., Khodaparast, M. H. H., Vosoughi, M., \& Diosady, L. L. (2005). Preparation of canola protein materials using membrane technology and evaluation of meals functional properties. Food Research International, 38(2), 223-231. https://doi.org/10.1016/j. foodres.2004.10.007.

González-Pérez, S., \& Arellano, J. B. (2009). 15 - Vegetable protein isolates. In G. O. Phillips \& P. A. Williams (Eds.), Handbook of Hydrocolloids (Second Edition) (pp. 383-419). Woodhead Publishing.

Guo, X., Han, D., Xi, H., Rao, L., Liao, X., Hu, X., \& Wu, J. (2012). Extraction of pectin from navel orange peel assisted by ultra-high pressure, microwave or traditional heating: A comparison. Carbohydrate Polymers, 88(2), 441-448.

Harrison, R. G., Todd, P. W., Rudge, S. R., \& Petrides, D. P. (2015). Bioseparations Science and Engineering (2nd ed.). Oxford University Press.

Hashimoto, K. (1983). Models for the separation of glucose/fructose mixture using a simulated moving-bed adsorber. Journal of Chemical Engineering of Japan, 16(5), 400-406.

Hashimoto, K. (1987). Continuous separation of glucose-salts mixture with nonlinear and linear adsorption isotherms by using a simulated moving-bed adsorber. Journal of Chemical Engineering of Japan, 20(4), 405-410.

Héder, M. (2017). From NASA to EU: the evolution of the TRL scale in Public Sector Innovation. The Innovation Journal, 22(2), 1-23.

Heiniö, R. L., Noort, M. W. J., Katina, K., Alam, S. A., Sozer, N., de Kock, H. L., Hersleth, M., \& Poutanen, K. (2016). Sensory characteristics of wholegrain and bran-rich cereal foods - A review. Trends in Food Science \& Technology, 47, 25-38. https://doi.org/10.1016/j. tifs.2015.11.002.
Hollmann, J., \& Lindhauer, M. G. (2005). Pilot-scale isolation of glucuronoarabinoxylans from wheat bran. Carbohydrate Polymers, 59(2), 225-230. https://doi.org/10.1016/j.carbpol.2004. 09.015 .

Islam, S., \& Ma, W. (2016). Lupine. In B. Caballero, P. M. Finglas, \& F. Toldrá (Eds.), Encyclopedia of Food and Health (pp. 579-585). Academic Press.

Karaca, A. C., Low, N., \& Nickerson, M. (2011). Emulsifying properties of canola and flaxseed protein isolates produced by isoelectric precipitation and salt extraction. Food Research International, 44(9), 2991-2998. https://doi.org/10.1016/j.foodres.2011.07.009.

Karefyllakis, D., van der Goot, A. J., \& Nikiforidis, C. V. (2019). Multicomponent emulsifiers from sunflower seeds. Current Opinion in Food Science, 29, 35-41. https://doi.org/10.1016/j.cofs. 2019.07.005

Kehili, M., Kammlott, M., Choura, S., Zammel, A., Zetzl, C., Smirnova, I., Allouche, N., \& Sayadi, S. (2017). Supercritical CO2 extraction and antioxidant activity of lycopene and $\beta$-carotene-enriched oleoresin from tomato (Lycopersicum esculentum L.) peels by-product of a Tunisian industry. Food and Bioproducts Processing, 102, 340-349. https://doi.org/10.1016/j.fbp.2017.02.002.

Kornet, C., Venema, P., Nijsse, J., van der Linden, E., van der Goot, A. J., \& Meinders, M. (2020). Yellow pea aqueous fractionation increases the specific volume fraction and viscosity of its dispersions. Food Hydrocolloids, 99, 105332. https://doi.org/10.1016/j.foodhyd.2019. 105332.

Kulkarni, S., \& Vijayanand, P. (2010). Effect of extraction conditions on the quality characteristics of pectin from passion fruit peel (Passiflora edulis f. flavicarpa L.). LWT- Food Science and Technology, 43(7), 1026-1031.

Lampitt, L. H., Money, R. W., Judge, B. E., \& Urie, A. (1947). Pectin studies. Part I. Method of purification. Journal of the Society of Chemical Industry, 66(4), 121-124. https://doi.org/10.1002/jctb. 5000660404.

Larrauri, J. A., Rupérez, P., \& Calixto, F. S. (1997). Pineapple Shell as a Source of Dietary Fiber with Associated Polyphenols. Journal of Agricultural and Food Chemistry, 45(10), 4028-4031. https://doi. org $10.1021 / \mathrm{j} 970450 \mathrm{j}$.

Lau, T., Harbourne, N., \& Oruña-Concha, M. J. (2019). Valorisation of sweet corn (Zea mays) cob by extraction of valuable compounds. 54(4), 1240-1246. https://doi.org/10.1111/ijfs.14092.

List, G. R. (2016). 2 - Oilseed Composition and Modification for Health and Nutrition. In T. A. B. Sanders (Ed.), Functional Dietary Lipids (pp. 23-46). Woodhead Publishing.

Liu, Y. Q., Strappe, P., Shang, W. T., \& Zhou, Z. K. (2019). Functional peptides derived from rice bran proteins. Critical Reviews in Food Science and Nutrition, 59(2), 349-356. https://doi.org/10.1080/ 10408398.2017.1374923.

Lomascolo, A., Uzan-Boukhris, E., Sigoillot, J.-C., \& Fine, F. (2012). Rapeseed and sunflower meal: a review on biotechnology status and challenges. [journal article]. Applied Microbiology and Biotechnology, 95(5), 1105-1114. https://doi.org/10.1007/s00253012-4250-6.

Lu, Z., Wang, J., Gao, R., Ye, F., \& Zhao, G. (2019). Sustainable valorisation of tomato pomace: A comprehensive review. Trends in Food Science \& Technology, 86, 172-187. https://doi.org/10. 1016/j.tifs.2019.02.020.

Mahato, N., Sharma, K., Koteswararao, R., Sinha, M., Baral, E., \& Cho, M. H. (2019). Citrus essential oils: Extraction, authentication and application in food preservation. Critical Reviews in Food Science and Nutrition, 59(4), 611-625. https://doi.org/10.1080/10408398. 2017.1384716.

Marshall Jr., H. F. (1990). Isolation and purification of cottonseed 7S storage protein and its subunits. Journal of Agricultural and Food Chemistry, 38(7), 1454-1457. 
Mateos-Aparicio, I., Redondo-Cuenca, A., Villanueva-Suárez, M.-J., Zapata-Revilla, M.-A., \& Tenorio-Sanz, M.-D. (2010). Pea pod, broad bean pod and okara, potential sources of functional compounds. LWT - Food Science and Technology, 43(9), 1467-1470. https://doi.org/10.1016/j.lwt.2010.05.008.

Mateos-Aparicio, I., Redondo-Cuenca, A., \& Villanueva-Suárez, M.-J. (2012). Broad bean and pea by-products as sources of fibre-rich ingredients: potential antioxidant activity measured in vitro. 92(3), 697-703. https://doi.org/10.1002/jsfa.4633.

May, C. D. (1990). Industrial pectins: Sources, production and applications. Carbohydrate Polymers, 12(1), 79-99. https://doi.org/10. 1016/0144-8617(90)90105-2.

Mirabella, N., Castellani, V., \& Sala, S. (2014). Current options for the valorization of food manufacturing waste: a review. Journal of Cleaner Production, 65, 28-41. https://doi.org/10.1016/j.jclepro. 2013.10.051.

Moreno-González, M., Girish, V., Keulen, D., Wijngaard, H., Lauteslager, X., Ferreira, G., \& Ottens, M. (2020). Recovery of sinapic acid from canola/rapeseed meal extracts by adsorption. Food and Bioproducts Processing, 120, 69-79. https://doi.org/10. 1016/j.fbp.2019.12.002.

Mourtzinos, I., \& Goula, A. (2019). Chapter 2 - Polyphenols in Agricultural Byproducts and Food Waste. In R. R. Watson (Ed.), Polyphenols in Plants (Second Edition) (pp. 23-44). Academic Press.

Mullen, A. M., Álvarez, C., Pojić, M., Hadnadev, T. D., \& Papageorgiou, M. (2015). Chapter 2 - Classification and target compounds. In C. M. Galanakis (Ed.), Food Waste Recovery (pp. 25-57). Academic Press.

Mussatto, S. I., Dragone, G., Guimarães, P. M. R., Silva, J. P. A., Carneiro, L. M., Roberto, I. C., Vicente, A., Domingues, L., \& Teixeira, J. A. (2010). Technological trends, global market, and challenges of bio-ethanol production. Biotechnology Advances, 28(6), 817-830. https://doi.org/10.1016/j.biotechadv.2010.07.001.

Naczk, M., \& Shahidi, F. (2006). Phenolics in cereals, fruits and vegetables: Occurrence, extraction and analysis. Journal of Pharmaceutical and Biomedical Analysis, 41(5), 1523-1542. https://doi.org/10.1016/j.jpba.2006.04.002.

Nawirska, A., \& Kwaśniewska, M. (2005). Dietary fibre fractions from fruit and vegetable processing waste. Food Chemistry, 91(2), 221225. https://doi.org/10.1016/j.foodchem.2003.10.005.

Nićiforović, N., \& Abramovič, H. (2014). Sinapic Acid and Its Derivatives: Natural Sources and Bioactivity. Comprehensive Reviews in Food Science and Food Safety, 13(1), 34-51. https:// doi.org/10.1111/1541-4337.12041.

Nunes, M. A., Pimentel, F. B., Costa, A. S. G., Alves, R. C., \& Oliveira, M. B. P. P. (2016). Olive by-products for functional and food applications: Challenging opportunities to face environmental constraints. Innovative Food Science \& Emerging Technologies, 35, 139-148. https://doi.org/10.1016/j.ifset.2016.04.016.

Orthoefer, F. T. (2005). Rice bran oil. In Bailey's industrial oil \& fat products (pp. 465-489). Wiley.

Patsioura, A., Galanakis, C. M., \& Gekas, V. (2011). Ultrafiltration optimization for the recovery of $\beta$-glucan from oat mill waste. Journal of Membrane Science, 373(1), 53-63. https://doi.org/10.1016/j. memsci.2011.02.032.

Pfaltzgraff, L. A., De Bruyn, M., Cooper, E. C., Budarin, V., \& Clark, J. H. (2013). Food waste biomass: a resource for high-value chemicals. [10.1039/C2GC36978H]. Green Chemistry, 15(2), 307-314. https://doi.org/10.1039/C2GC36978H.

Pickardt, C., Eisner, P., Kammerer, D. R., \& Carle, R. (2015). Pilot plant preparation of light-coloured protein isolates from de-oiled sunflower (Helianthus annuus L.) press cake by mild-acidic protein extraction and polyphenol adsorption. Food Hydrocolloids, 44, 208-219. https://doi.org/10.1016/j.foodhyd.2014.09.020.
Prakash, J., \& Ramaswamy, H. S. (1996). Rice bran proteins: Properties and food uses. Critical Reviews in Food Science and Nutrition, 36(6), 537-552. https://doi.org/10.1080/10408399609527738.

Prival, M. J. (2003). CANCER | Carcinogens in the Food Chain. In B. Caballero (Ed.), Encyclopedia of Food Sciences and Nutrition (2nd ed., pp. 799-804). Academic Press.

Rezzadori, K., Benedetti, S., \& Amante, E. (2012). Proposals for the residues recovery: Orange waste as raw material for new products. Food and Bioproducts Processing, 90(4), 606-614.

Roda, A., \& Lambri, M. (2019). Food uses of pineapple waste and byproducts: a review. 54(4), 1009-1017. https://doi.org/10.1111/ijfs. 14128.

Rodriguez de Soltillo, D., Hadley, M., \& Holm, E. T. (1994). Potato Peel Waste: Stability and Antioxidant Activity of a Freeze-Dried Extract. 59(5), 1031-1033. https://doi.org/10.1111/j.1365-2621.1994. tb08182.x.

Rodríguez Madrera, R., Pando Bedriñana, R., García Hevia, A., Arce, M. B., \& Suárez Valles, B. (2013). Production of spirits from dry apple pomace and selected yeasts. Food and Bioproducts Processing, 91(4), 623-631. https://doi.org/10.1016/j.fbp.2013.04.005.

Roque, A. C. A., Pina, A. S., Azevedo, A. M., Aires-Barros, R., Jungbauer, A., Di Profio, G., Heng, J. Y. Y., Haigh, J., \& Ottens, M. (2020). Anything but Conventional Chromatography Approaches in Bioseparation. Biotechnology Journal, 15(8), 1900274.

Rosa-Sibakov, N., Poutanen, K., \& Micard, V. (2015). How does wheat grain, bran and aleurone structure impact their nutritional and technological properties? Trends in Food Science \& Technology, 41(2), 118-134. https://doi.org/10.1016/j.tifs.2014.10.003.

Rosell, C. M., \& Garzon, R. (2015). Chemical Composition of Bakery Products. In P. C. K. Cheung \& B. M. Mehta (Eds.), Handbook of Food Chemistry (pp. 191-224). Springer Berlin Heidelberg.

Saberian, H., Hamidi-Esfahani, Z., Gavlighi, H. A., \& Barzegar, M. (2017). Optimization of pectin extraction from orange juice waste assisted by ohmic heating. Chemical Engineering and Processing: Process Intensification, 117, 154-161.

Saffarionpour, S., \& Ottens, M. (2018). Recent Advances in Techniques for Flavor Recovery in Liquid Food Processing. Food Engineering Reviews, 10(2), 81-94. https://doi.org/10.1007/s12393-017-9172-8.

Sari, Y. W., Syafitri, U., Sanders, J. P. M., \& Bruins, M. E. (2015). How biomass composition determines protein extractability. Industrial Crops and Products, 70, 125-133. https://doi.org/10.1016/j. indcrop.2015.03.020.

Schieber, A., \& Saldaña, M. D. (2009). Potato peels: a source of nutritionally and pharmacologically interesting compounds-a review. Food, 3(Special Issue 2), 23-29. https://doi.org/10.7939/ R33T9DM0H.

Schieber, A., Hilt, P., Streker, P., Endreß, H.-U., Rentschler, C., \& Carle, R. (2003). A new process for the combined recovery of pectin and phenolic compounds from apple pomace. Innovative Food Science \& Emerging Technologies, 4(1), 99-107. https://doi.org/10.1016/ S1466-8564(02)00087-5.

Scordino, M., Di Mauro, A., Passerini, A., \& Maccarone, E. (2007). Highly purified sugar concentrate from a residue of citrus pigments recovery process. LWT - Food Science and Technology, 40(4), 713721. https://doi.org/10.1016/j.lwt.2006.03.007.

Seguí Gil, L., \& Fito Maupoey, P. (2018). An integrated approach for pineapple waste valorisation. Bioethanol production and bromelain extraction from pineapple residues. Journal of Cleaner Production, 172, 1224-1231. https://doi.org/10.1016/j.jclepro.2017.10.284.

Seider, W. D., Seader, J. D., Lewin, D. R., \& Widagdo, S. (2010). Product and process design principles : synthesis, analysis, and evaluation (3rd ed.). Wiley.

Sevillano, D. M., van der Wielen, L. A. M., Hooshyar, N., \& Ottens, M. (2014). Resin selection for the separation of caffeine from green tea 
catechins. Food and Bioproducts Processing, 92(2), 192-198. https://doi.org/10.1016/j.fbp.2014.02.002.

Sewekow, E., Kessler, L. C., Seidel-Morgenstern, A., \& Rothkötter, H.-J. (2008). Isolation of soybean protein P34 from oil bodies using hydrophobic interaction chromatography. BMC Biotechnology, 8(1), 27.

Shahidi, F., Alasalvar, C., \& Liyana-Pathirana, C. M. (2007). Antioxidant Phytochemicals in Hazelnut Kernel (Corylus avellana L.) and Hazelnut Byproducts. Journal of Agricultural and Food Chemistry, 55(4), 1212-1220. https://doi.org/10.1021/jf062472o.

Sharma, K. D., Karki, S., Thakur, N. S., \& Attri, S. (2012). Chemical composition, functional properties and processing of carrot-a review. Journal of Food Science and Technology, 49(1), 22-32. https://doi.org/10.1007/s13197-011-0310-7.

Shi, M., Hlaing, M. M., Ying, D., Ye, J., Sanguansri, L., \& Augustin, M. A. (2019). New food ingredients from broccoli by-products: physical, chemical and technological properties. 54(4), 1423-1432, https://doi.org/10.1111/ijfs.14111.

Shukla, B. D., Srivastava, P. K., \& Gupta, R. K. (1992). Oilseeds Processing Technology. India Central Institute of Agricultural Engineering.

Siles López, J. A., Li, Q., \& Thompson, I. P. (2010). Biorefinery of waste orange peel. Critical Reviews in Biotechnology, 30(1), 63-69.

Silva, M., Castellanos, L., \& Ottens, M. (2018a). Capture and Purification of Polyphenols Using Functionalized Hydrophobic Resins. Industrial \& Engineering Chemistry Research, 57(15), 53595369. https://doi.org/10.1021/acs.iecr.7b05071.

Silva, M., García, J. C., \& Ottens, M. (2018b). Polyphenol Liquid-Liquid Extraction Process Development Using NRTL-SAC. Industrial \& Engineering Chemistry Research, 57(28), 9210-9221. https://doi. org/10.1021/acs.iecr.8b00613.

Silva, M., Vieira, B., \& Ottens, M. (2018c). Preferential crystallization for the purification of similar hydrophobic polyphenols. Journal of Chemical Technology \& Biotechnology, 93(7), 1997-2010. https:// doi.org/10.1002/jctb.5526.

Siriwardhana, S. S. K. W., \& Shahidi, F. (2002). Antiradical activity of extracts of almond and its by-products. Journal of the American Oil Chemists' Society, 79(9), 903-908. https://doi.org/10.1007/s11746002-0577-4.

Smith, P. G. (2011). Evaporation and Drying. In Introduction to Food Process Engineering (pp. 299-334). Springer US.

Sohail, M., Rakha, A., Butt, M. S., Iqbal, M. J., \& Rashid, S. (2017). Rice bran nutraceutics: A comprehensive review. Critical Reviews in Food Science and Nutrition, 57(17), 3771-3780. https://doi.org/ 10.1080/10408398.2016.1164120.

Soto, M. L., Moure, A., Domínguez, H., \& Parajó, J. C. (2011). Recovery, concentration and purification of phenolic compounds by adsorption: a review. Journal of Food Engineering, 105(1), 127.

Steinebach, F., Muller-Spath, T., \& Morbidelli, M. (2016). Continuous counter-current chromatography for capture and polishing steps in biopharmaceutical production. Biotechnology Journal, 11(9), 11261141.

Stoll, T., Schweiggert, U., Schieber, A., \& Carle, R. (2003). Process for the recovery of a carotene-rich functional food ingredient from carrot pomace by enzymatic liquefaction. Innovative Food Science \& Emerging Technologies, 4(4), 415-423. https://doi.org/10.1016/ S1466-8564(03)00060-2.

Sudha, M. L. (2011). Chapter 36 - Apple Pomace (By-Product of Fruit Juice Industry) as a Flour Fortification Strategy. In V. R. Preedy, R. R. Watson, \& V. B. Patel (Eds.), Flour and Breads and their
Fortification in Health and Disease Prevention (pp. 395-405). Academic Press.

Sun, S., Sun, S., Cao, X., \& Sun, R. (2016). The role of pretreatment in improving the enzymatic hydrolysis of lignocellulosic materials. Bioresource Technology, 199, 49-58. https://doi.org/10.1016/j. biortech.2015.08.061.

Szwajgier, D., \& Borowiec, K. (2012). Phenolic acids from malt are efficient acetylcholinesterase and butyrylcholinesterase inhibitors. 118(1), 40-48. https://doi.org/10.1002/jib.5.

Thiel, A., Muffler, K., Tippkötter, N., Suck, K., Sohling, U., Hruschka, S. M., \& Ulber, R. (2015). A novel integrated downstream processing approach to recover sinapic acid, phytic acid and proteins from rapeseed meal. Journal of Chemical Technology and Biotechnology, 90(11), 1999-2006.

Topal, U., Sasaki, M., Goto, M., \& Hayakawa, K. (2006). Extraction of Lycopene from Tomato Skin with Supercritical Carbon Dioxide: Effect of Operating Conditions and Solubility Analysis. Journal of Agricultural and Food Chemistry, 54(15), 5604-5610. https://doi. org/10.1021/jf0606407.

Towler, G. P., \& Sinnott, R. K. (2013). Chemical engineering design : principles, practice, and economics of plant and process design (2nd ed.). Butterworth-Heinemann.

Truong, V.-D., McFeeters, R. F., Thompson, R. T., Dean, L. L., \& Shofran, B. (2007). Phenolic Acid Content and Composition in Leaves and Roots of Common Commercial Sweetpotato (Ipomea batatas L.) Cultivars in the United States. 72(6), C343-C349. https:// doi.org/10.1111/j.1750-3841.2007.00415.x.

Tuck, C. O., Pérez, E., Horváth, I. T., Sheldon, R. A., \& Poliakoff, M. (2012). Valorization of Biomass: Deriving More Value from Waste. Science, 337(6095), 695-699. https://doi.org/10.1126/science. 1218930.

Ubalua, A. O. (2007). Cassava wastes: treatment options and value addition alternatives. African Journal of Biotechnology, 6(18), 20652073.

Versino, F., López, O. V., \& García, M. A. (2015). Sustainable use of cassava (Manihot esculenta) roots as raw material for biocomposites development. Industrial Crops and Products, 65, 79-89. https://doi. org/10.1016/j.indcrop.2014.11.054.

Virtanen, S., Chowreddy, R. R., Irmak, S., Honkapää, K., \& Isom, L. (2016). Food Industry Co-streams: Potential Raw Materials for Biodegradable Mulch Film Applications. [journal article]. Journal of Polymers and the Environment, 1-21. https://doi.org/10.1007/ s10924-016-0888-y.

Vuorela, S., Meyer, A. S., \& Heinonen, M. (2004). Impact of isolation method on the antioxidant activity of rapeseed meal phenolics. Journal of Agricultural and Food Chemistry, 52(26), 8202-8207.

Wanasundara, J. P. D. (2011). Proteins of Brassicaceae oilseeds and their potential as a plant protein source. Critical Reviews in Food Science and Nutrition, 51(7), 635-677.

Wanasundara, J. P. D., McIntosh, T. C., Perera, S. P., Withana-Gamage, T. S., \& Mitra, P. (2016). Canola/rapeseed protein-functionality and nutrition. OCL, 23(4), D407.

Wang, W., Ma, X., Xu, Y., Cao, Y., Jiang, Z., Ding, T., Ye, X., \& Liu, D. (2015). Ultrasound-assisted heating extraction of pectin from grapefruit peel: Optimization and comparison with the conventional method. Food Chemistry, 178, 106-114.

Weisz, G. M., Schneider, L., Schweiggert, U., Kammerer, D. R., \& Carle, R. (2010). Sustainable sunflower processing - I. Development of a process for the adsorptive decolorization of sunflower [Helianthus annuus L.] protein extracts. Innovative Food Science and Emerging Technologies, 11(4), 733-741. https://doi.org/10.1016/j.ifset.2010. 05.005 . 
Xu, L., \& Diosady, L. L. (2002). Removal of phenolic compounds in the production of high-quality canola protein isolates. Food Research International, 35(1), 23-30. https://doi.org/10.1016/S09639969(00)00159-9.

Zhang, C., \& Glatz, C. E. (1999). Process engineering strategy for recombinant protein recovery from canola by cation exchange chromatography. Biotechnology Progress, 15(1), 12-18.

Zhang, K., Pei, Z., \& Wang, D. (2016). Organic solvent pretreatment of lignocellulosic biomass for biofuels and biochemicals: A review.
Bioresource Technology, 199, 21-33. https://doi.org/10.1016/j. biortech.2015.08.102.

Zhang, H., Birch, J., Pei, J., Ma, Z. F., \& Bekhit, A. E.-D. (2019). Phytochemical compounds and biological activity in Asparagus roots: a review. 54(4), 966-977. https://doi.org/10.1111/ijfs.13993.

Publisher's Note Springer Nature remains neutral with regard to jurisdictional claims in published maps and institutional affiliations. 